\title{
Projected Change in Temperature and Precipitation Over Africa from CMIP6
}

\author{
Mansour Almazroui ${ }^{1}$ [ $\cdot$ Fahad Saeed $^{1,2} \cdot$ Sajjad Saeed $^{1,3,4} \cdot$ M. Nazrul Islam ${ }^{1} \cdot$ Muhammad Ismail $^{1}$. \\ Nana Ama Browne Klutse ${ }^{5}$. Muhammad Haroon Siddiqui ${ }^{1}$
}

Received: 29 December 2019 / Accepted: 8 June 2020 / Published online: 2 July 2020

(c) The Author(s) 2020

\begin{abstract}
We analyze data of 27 global climate models from the sixth phase of the Coupled Model Intercomparison Project (CMIP6), and examine projected changes in temperature and precipitation over the African continent during the twenty-first century. The temperature and precipitation changes are computed for two future time slices, 2030-2059 (near term) and 2070-2099 (long term), relative to the present climate (1981-2010), for the entire African continent and its eight subregions. The CMIP6 multi-model ensemble projected a continuous and significant increase in the mean annual temperature over all of Africa and its eight subregions during the twenty-first century. The mean annual temperature over Africa for the near (long)-term period is projected to increase by $1.2^{\circ} \mathrm{C}\left(1.4{ }^{\circ} \mathrm{C}\right), 1.5^{\circ} \mathrm{C}\left(2.3^{\circ} \mathrm{C}\right)$, and $1.8{ }^{\circ} \mathrm{C}\left(4.4{ }^{\circ} \mathrm{C}\right)$ under the Shared Socioeconomic Pathways (SSPs) for weak, moderate, and strong forcing, referenced as SSP1-2.6, SSP2-4.5, and SSP5-8.5, respectively. The future warming is not uniform over Africa and varies regionally. By the end of the twenty-first century, the largest rise in mean annual temperature $\left(5.6{ }^{\circ} \mathrm{C}\right)$ is projected over the Sahara, while the smallest rise $\left(3.5^{\circ} \mathrm{C}\right)$ is over Central East Africa, under the strong forcing SSP5-8.5 scenario. The projected boreal winter and summer temperature patterns for the twenty-first century show spatial distributions similar to the annual patterns. Uncertainty associated with projected temperature over Africa and its eight subregions increases with time and reaches a maximum by the end of the twenty-first century. On the other hand, the precipitation projections over Africa during the twenty-first century show large spatial variability and seasonal dependency. The northern and southern parts of Africa show a reduction in precipitation, while the central parts of Africa show an increase, in future climates under the three reference scenarios. For the near (long)-term periods, the area-averaged precipitation over Africa is projected to increase by $6.2(4.8) \%, 6.8(8.5) \%$, and 9.5 (15.2)\% under SSP1-2.6, SSP2-4.5, and SSP5-8.5, respectively. The median warming simulated by the CMIP6 model ensemble remains higher than the CMIP5 ensemble over most of Africa, reaching as high as $2.5^{\circ} \mathrm{C}$ over some regions, while precipitation shows a mixed spatial pattern.
\end{abstract}

Keywords Africa $\cdot$ Precipitation $\cdot$ Temperature $\cdot$ CMIP6 $\cdot$ Future climate projections

Electronic supplementary material The online version of this article (https://doi.org/10.1007/s41748-020-00161-x) contains supplementary material, which is available to authorized users.

Mansour Almazroui

mansour@kau.edu.sa

1 Center of Excellence for Climate Change Research/ Department of Meteorology, King Abdulaziz University, PO Box 80208, Jeddah 21589, Saudi Arabia

2 Climate Analytics, Berlin, Germany

3 The Abdus Salam International Center for Theoretical Physics, Trieste, Italy

4 Department of Earth and Environmental Sciences, KU Leuven, Leuven, Belgium

5 Department of Physics, University of Ghana, Accra, Ghana

\section{Introduction}

Africa, the second most populous continent in the world, is one of the regions most vulnerable to climate change due to its high exposure and low adaptive capacity (Sutton et al. 2011; Barros et al. 2014). Previous studies (e.g. Christy et al. 2009; Jones and Moberg 2003; Kruger and Shongwe 2004; Mohamed 2011; Nicholson et al. 2013; Stern et al. 2011; Trenberth 2007) have reported a rise in observed near-surface temperature over most of Africa of approx. $0.5^{\circ} \mathrm{C}$ during the past $50-100$ years. Collins (2011) found a significant increase in the nearsurface temperature anomalies over Africa in recent years (1995-2010) as compared with 1979-1994. Due to its 
large latitudinal extent, the climate of the African continent varies widely. Barkhordarian et al. (2012) found an increasing trend in the observed annual and seasonal mean surface temperatures over North Africa. Several other studies also identified a projected increase in the mean temperature over North Africa and adjacent areas of the Middle East and Arabian Peninsula during the twenty-first century (Bucchignani et al. 2018; Almazroui et al. 2017a, b; Lelieveld et al. 2012, 2016; Vizy and Cook 2012). According to the fifth assessment report of the Intergovernmental Panel on Climate Change (IPCC AR5, IPCC 2013), projected average air temperature over Africa could exceed the twentieth-century range of variability by 2047 and 2069, under Representative Concentration Pathways (RCPs) RCP8.5 and RCP4.5, respectively (Niang et al. 2015). The northern part of Africa and the Middle Eastern regions adjacent to the Mediterranean have been identified as hotspots for climate change (Giorgi and Lionello 2008). New et al. (2006) found fewer cold days and cold nights and more warm days and warm nights over West Africa during the period 1961-2006. The risk of deadly heat stress is likely to increase over West Africa, while heat waves are likely to be more frequent and longer under the effects of global warming (Diedhiou et al. 2018; Sylla et al. 2018). Anyah and Qiu (2012) similarly observed an increase in temperature over the southern and eastern parts of Africa in recent decades. Consistent with these results, most parts of southern Africa have also experienced an increasing trend in mean annual temperature in recent decades (Collins 2011; Kruger and Sekele 2013; MacKellar et al. 2014).

On the other hand, precipitation over the African continent is highly variable. Available observational datasets show large discrepancies over Africa (Kruger and Shongwe 2004; Nikulin et al. 2012; Kalognomou et al. 2013; Sylla et al. 2013), and therefore it is difficult to draw robust conclusions about precipitation trends during the past century. According to IPCC AR5, mean annual precipitation decreased over the western and eastern Sahel regions in northern Africa, while it increased over parts of eastern and southern Africa, in the past century (IPCC 2013). Observed precipitation over Africa also displays strong seasonal variability. The boreal winter and spring precipitation over northern Africa show a decreasing trend in recent decades (Barkhordarian et al. 2013). The Sahara desert in northern Africa receives very low mean annual precipitation and likewise shows little seasonal change in precipitation (Liebmann et al. 2012). The overall reduction in seasonal and annual precipitation over different parts of the African continent during the twentieth century is also noted by several other studies (Sylla et al. 2016, 2018;
Klutse et al. 2018) (Hoerling et al. 2006; Lebel and Ali 2009; Lyon and Dewitt 2012; Mohamed 2011; New et al. 2006).

Future climate projections over Africa for the twentyfirst century indicate that its land temperature will rise faster than the global mean temperature, particularly in the more arid regions (Niang et al. 2015). Under high-emission RCP8.5, the mean annual temperature over Africa could rise by $3-6{ }^{\circ} \mathrm{C}$ by the end of the twenty-first century. Precipitation projections are more uncertain than temperature projections and display larger spatial variability and seasonal dependence (Orlowsky and Seneviratne 2012). IPCC's fifth assessment report projected a reduction in precipitation over northern Africa and southwestern parts of South Africa by the end of the twenty-first century (Niang et al. 2015). The IPCC climate projections for Africa are based mainly on Coupled Model Intercomparison Project phase 3 and phase 5 (formally known as CMIP3 and CMIP5) datasets. Data from the more recent phase 6 of the Coupled Model Intercomparison Project are now available for analysis (Eyring et al. 2016). The CMIP6 dataset differs from CMIP5 and CMIP3 datasets in terms of forcing scenarios and carbon emissions. The CMIP6 project employed updated versions of the coupled global climate models, a new start year, and a new set of Shared Socioeconomic Pathways (SSP) scenarios of concentrations (Gidden et al. 2019). The present study, therefore, aims to examine the projected changes in future temperature and precipitation over Africa using the latest CMIP6 dataset. This paper further describes projected annual and seasonal mean changes in temperature and precipitation over eight African subregions (described in the next section).

\section{Data and Methodology}

First, observational temperature data from the Climatic Research Unit (CRU) (Harris et al. 2014) and precipitation data from the Global Precipitation Climatology Centre (GPCC) (Becker et al. 2013) were analyzed to depict temperature and precipitation climatology over Africa for the period 1981-2010. In a second step, we analyzed the multi-model ensemble from 27 CMIP6 models (listed in Table 1) and examined future changes in temperature and precipitation over Africa in the twenty-first century. Analyses were performed over the entire African continent as well as over eight subregions (Fig. 1). These eight subregions are as follows: North Africa (NAF), Sahara (SAH), West Africa (WAF), Central Africa (CAF), Central East Africa (CEAF), North East Africa (NEAF), South West Africa (SWAF), and South East Africa (SEAF) (see Iturbide et al. 2020). The subregions are defined for the IPCC's sixth assessment 
Table 1 List of CMIP6 models used in this study along with horizontal resolution and country of origin

\begin{tabular}{|c|c|c|c|c|c|}
\hline No. & CMIP6 model name & Country & $\begin{array}{l}\text { Horizontal resolution } \\
\text { (lon. by lat. in degrees) }\end{array}$ & Variant label & Key references \\
\hline 1 & ACCESS-CM2 & Australia & $1.9^{\circ} \times 1.3^{\circ}$ & rli1p1f1 & Bi et al. (2012) \\
\hline 2 & ACCESS-ESM1-5 & Australia & $1.9^{\circ} \times 1.2^{\circ}$ & r1ilp1f1 & Law et al. (2017) \\
\hline 3 & BCC-CSM2-MR & China & $1.1^{\circ} \times 1.1^{\circ}$ & rli1p1f1 & Wu et al. (2019) \\
\hline 4 & CAMS-CSM1-0 & China & $1.1^{\circ} \times 1.1^{\circ}$ & r1i1p1f1 & Rong et al. (2019) \\
\hline 5 & CanESM5 & Canada & $2.8^{\circ} \times 2.8^{\circ}$ & r1i1p1f1 & Swart et al. (2019) \\
\hline 6 & CESM2 & USA & $1.3^{\circ} \times 0.9^{\circ}$ & r1i1p1f1 & Lauritzen et al. (2018) \\
\hline 7 & CESM2-WACCM & USA & $1.3^{\circ} \times 0.9^{\circ}$ & r1ilp1f1 & Li et al. (2019) \\
\hline 8 & CNRM-CM6-1 & France & $1.4^{\circ} \times 1.4^{\circ}$ & r1i1p1f2 & Voldoire et al. (2019) \\
\hline 9 & CNRM-CM6-1-HR & France & $0.5^{\circ} \times 0.5^{\circ}$ & r1ilp1f2 & Voldoire et al. (2019) \\
\hline 10 & CNRM-ESM2-1 & France & $1.4^{\circ} \times 1.4^{\circ}$ & r1ilp1f2 & Séférian et al. (2019) \\
\hline 11 & EC-Earth3 & Europe & $0.7^{\circ} \times 0.7^{\circ}$ & r1ilp1f1 & Massonnet et al. (2020) \\
\hline 12 & EC-Earth3-Veg & Europe & $0.7^{\circ} \times 0.7^{\circ}$ & rli1p1f1 & Not available \\
\hline 13 & FGOALS-f3-L & China & $1.3^{\circ} \times 1^{\circ}$ & rli1p1f1 & He et al. (2019) \\
\hline 14 & FGOALS-g3 & China & $2^{\circ} \times 2.3^{\circ}$ & r1ilp1f1 & Not available \\
\hline 15 & FIO-ESM-2-0 & China & $1.3^{\circ} \times 0.9^{\circ}$ & r1i1p1f1 & Song et al. (2019) \\
\hline 16 & GFDL-ESM4 & USA & $1.3^{\circ} \times 1^{\circ}$ & r1i1p1f1 & Held et al. (2019) \\
\hline 17 & INM-CM4-8 & Russia & $2^{\circ} \times 1.5^{\circ}$ & rli1p1f1 & Volodin et al. (2018) \\
\hline 18 & INM-CM5-0 & Russia & $2^{\circ} \times 1.5^{\circ}$ & r1ilp1f1 & Volodin et al. (2018) \\
\hline 19 & IPSL-CM6A-LR & France & $2.5^{\circ} \times 1.3^{\circ}$ & r1ilp1f1 & Not available \\
\hline 20 & MIROC6 & Japan & $1.4^{\circ} \times 1.4^{\circ}$ & r1ilp1f1 & Tatebe et al. (2019) \\
\hline 21 & MIROC-ES2L & Japan & $2.8^{\circ} \times 2.8^{\circ}$ & r1i1p1f2 & Hajima et al. (2019) \\
\hline 22 & MPI-ESM1-2-HR & Germany & $0.9^{\circ} \times 0.9^{\circ}$ & rli1p1f1 & Gutjahr et al. (2019) \\
\hline 23 & MPI-ESM1-2-LR & Germany & $1.9^{\circ} \times 1.9^{\circ}$ & r1ilp1f1 & Mauritsen et al. (2019) \\
\hline 24 & MRI-ESM2-0 & Japan & $1.1^{\circ} \times 1.1^{\circ}$ & r1ilp1f1 & Yukimoto et al. (2019) \\
\hline 25 & NESM3 & China & $1.9^{\circ} \times 1.9^{\circ}$ & r1i1p1f1 & Cao et al. (2018) \\
\hline 26 & NorESM2-LM & Norway & $2.5^{\circ} \times 1.9^{\circ}$ & r1ilp1f1 & Seland et al. (2020) \\
\hline 27 & UKESM1-0-LL & UK & $1.9^{\circ} \times 1.3^{\circ}$ & r1ilp1f2 & Sellar et al. (2019) \\
\hline
\end{tabular}

report (AR6), and the rationale behind selecting these subregions is explained in detail by Iturbide et al. (2020). The CMIP6 dataset was obtained from the CMIP6 database (https://esgf-node.1lnl.gov/search/cmip6). This CMIP6 dataset is available at different horizontal resolutions. Prior to the analysis, we re-gridded all CMIP6 data from original spatial resolutions to a $1^{\circ} \times 1^{\circ}$ common grid resolution owing to the higher resolution of CMIP6 models, which is explained in detail by Iturbide et al. (2020). To accomplish this, a bilinear re-gridding method is applied to temperature data, and a conservative first-order re-gridding to precipitation data. Previous studies (Jones 1999; Saeed et al. 2017) also reported that a conservative re-gridding method is more appropriate for discontinuous variables like precipitation.

We first examined the performance of the CMIP6 models over Africa in the present climate (1981-2010) against the CRU observations. For this purpose, we computed the temperature and precipitation biases for each sub-region as well as for all of Africa, and examined the spread in bias for the 27 CMIP6 models. For future projections, the mean annual temperature and precipitation data were analyzed over 30-year time intervals for the base period (1981-2010), the near term (2030-2059), and the long term (2070-2099). Temperature and precipitation trends were then examined for a continuous period from 2030 to 2099. Since there is large seasonal variation over Africa, we also examined temperature and precipitation projections for boreal summer (JJA) and winter (DJF) seasons. The ensemble from the 27 available CMIP6 models for the present and future climates was analyzed for temperature and precipitation changes under three future SSP scenarios, namely a low forcing scenario SSP1-2.6, a medium forcing scenario SSP2-4.5, and a strong forcing scenario SSP5-8.5. All SSPs are based on five narratives that describe alternative socioeconomic developments (Gidden et al. 2019). These include sustainable development (SSP1), middle-of-the-road development (SSP2), regional rivalry (SSP3), inequality (SSP4), and fossil-fueled development (SSP5). Complete descriptions of SSPs are available in O'Neill et al. (2016). SSP1-2.6, SSP2-4.5, and SSP5-8.5 


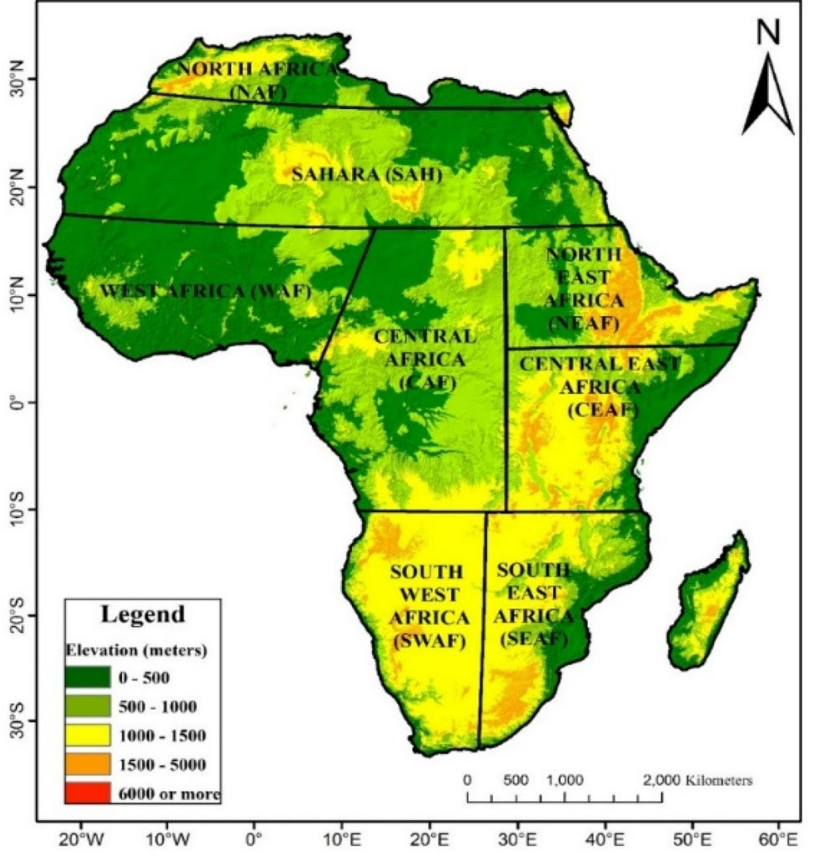

Fig. 1 Map displaying the study area and elevation over Africa. The elevation is shown in meters. The eight subregions used in this study are shown with solid lines

are taken to be representatives of low-, medium-. and highemission scenarios, respectively.

For the evaluation of future temperature and precipitation under SSPs in the form of spatial plots, two criteria based on the robustness and significance of change were employed. The robustness of the projected signal is a measure based on the agreement of different model projections in the direction of changes (Solomon et al. 2007). The changes, whether an increase or a decrease in the projected signal, are robust if at least $66 \%$ of the models agree on the change direction (Haensler et al. 2013; Almazroui et al. 2017a, b). The significance of a change in the projected signal was measured by employing a two-tailed Student $t$ test based on equal and unequal variances between future and historical data for each grid box. Equal and unequal variance was determined for each grid box using an $F$ test. To assess the uncertainty associated with the temperature and precipitation over Africa, the $66 \%$ likely range (17th-83rd percentile) and the full range (results from all models) were also used along with median values. Finally, we examined the difference between CMIP6 and CMIP5 projections (Table S1) to assess the climate response to the anthropogenic forcings in both sets of CMIP model simulations over Africa.

\section{Results and Discussion}

\subsection{Observed Climatology and Climate Models' Evaluation}

The observed mean annual temperature and precipitation over Africa during the period 1981-2010 is shown in Fig. 2a, b. The mean annual temperature varies widely from 10 to $30{ }^{\circ} \mathrm{C}$ (Fig. 2a). The lowest values of mean annual temperature $\left(<15{ }^{\circ} \mathrm{C}\right)$ occur over NAF, SWAF, SEAF, and some hilly areas of CEAF and NEAF. The highest values of mean annual temperature $\left(>28{ }^{\circ} \mathrm{C}\right)$ occur in the western parts of SAH and WAF, northern parts of $\mathrm{CAF}, \mathrm{NEAF}$, and adjacent areas of SAH, and eastern boundaries of NEAF and CEAF (Fig. 2a).

Unlike temperature, precipitation over Africa is highly variable. Most of the mean annual precipitation over Africa during 1981-2010 occurred between $10^{\circ} \mathrm{N}$ and $20^{\circ} \mathrm{N}$. The NAF receives mean annual precipitation amounting to $\sim 200-500 \mathrm{~mm}$ year $^{-1}$. The rainfall over NAF is highly variable and season-dependent. The smallest amount of precipitation occurs in $\mathrm{SAH}$, and ranges from 25 to $100 \mathrm{~mm}_{\text {year }}{ }^{-1}$. The coastal areas of WAF and central parts of CAF and NEAF and Madagascar receive the highest amount of annual rainfall, reaching $3000 \mathrm{~mm} \mathrm{year}^{-1}$. Rainfall over central parts of Africa is highly dependant on the seasonal March of the Intertropical Convergence Zone (ITCZ). During the boreal winter season, rain falls mostly in the Southern Hemisphere between 0 and $20^{\circ} \mathrm{S}$, while during the boreal summer season the ITCZ moves to the Northern Hemisphere, and thus rain falls between 0 and $20^{\circ} \mathrm{N}$ (Fig. 2b).

Figure 2c, d displays the performance of the CMIP6 models in the simulation of mean annual temperature and precipitation over Africa in the present climate with respect to the observations. The length of each bar shows the spread in temperature and precipitation biases simulated by the CMIP6 models over all regions and over the entire continent relative to CRU observations. For temperature, in each region except NEAF, the ensemble median tends to remain slightly below the zero line. However, the $66 \%$ range around the median spans the zero line. Precipitation results show a mixed pattern, where the ensemble median lies above and below the zero line for different regions. Similarly, the $66 \%$ range spans the zero line for all regions except SWAF, which has a large wet bias. A similar wet bias is observed over the SWAF region for the CMIP5 models, and is associated with the enhanced northeasterly moisture influx (Munday and Washington 2018). The SAH region is hyper-arid and has a poor density of observation stations, which results in a huge bias in relative plots for precipitation. Therefore, results for 

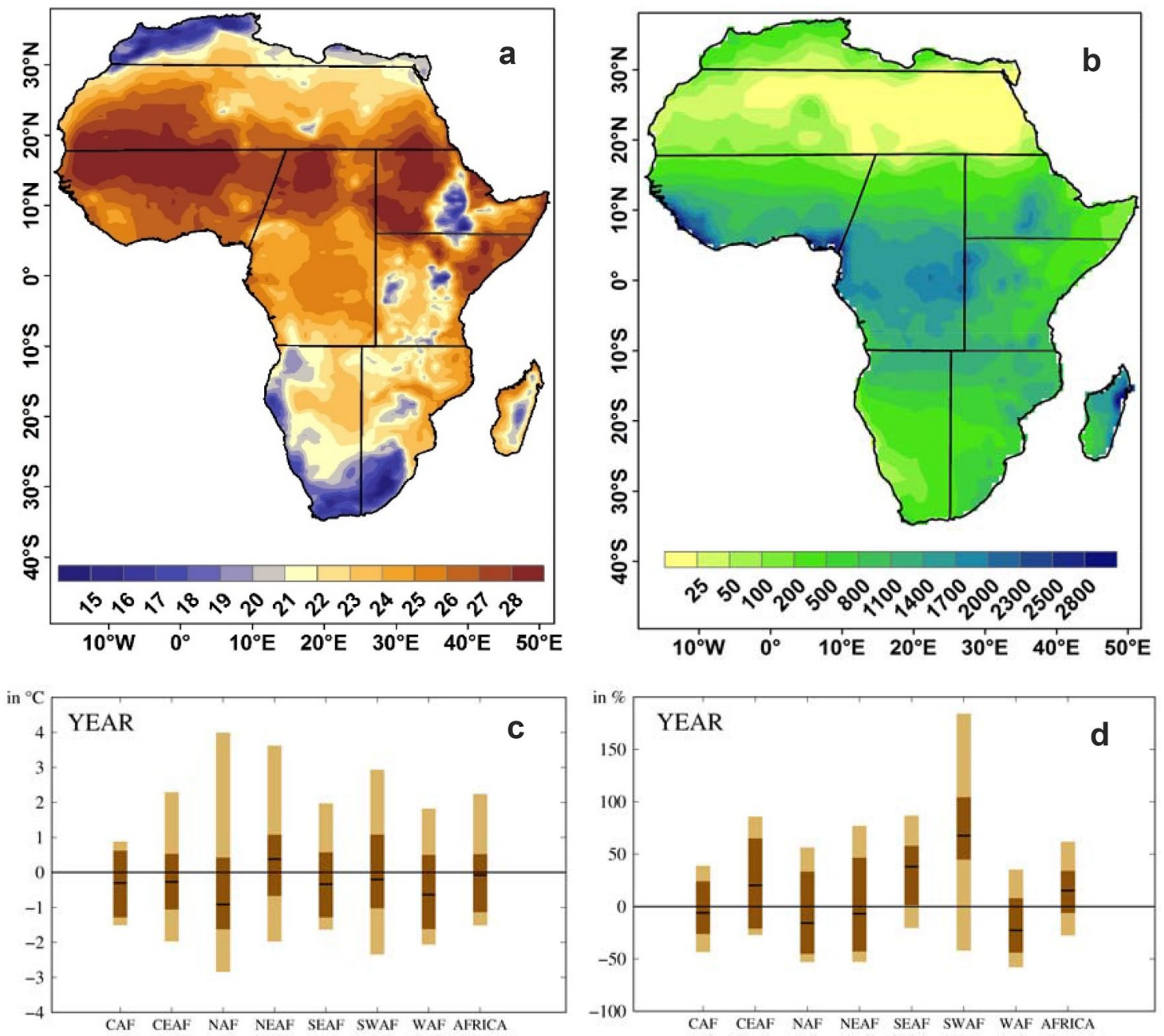

Fig. 2 Observed a mean annual temperature $\left({ }^{\circ} \mathbf{C}\right)$ and $\mathbf{b}$ precipitation $\left(\mathrm{mm} \mathrm{year}^{-1}\right)$ climatology over Africa. The temperature and precipitation climatologies are computed using the CRU and GPCC datasets, respectively, for the period $1981-2010$. Biases in $\mathbf{c}$ temperature $\left({ }^{\circ} \mathrm{C}\right)$

and $\mathbf{d}$ precipitation (\%) simulated by CMIP6 models over Africa and its subregions. The median bias is shown by the black horizontal line in each bar. The length of the bar shows the full range, while the dark shades represent the $66 \%$ range around the median bias

this region are not displayed in Fig. 2c, d. The next section describes changes in future rainfall and temperature over Africa.

\subsection{Change in Multi-Model Mean Annual Temperature and Precipitation Projections Over Africa}

The spatial distribution of projected changes in mean annual temperature and precipitation over Africa is shown in Figs. 3 and 4. The future temperature projections indicate enhanced warming over Africa, during both the near- and long-term periods during the twenty-first century relative to the reference climate, under all three future scenarios (Fig. 3). The warming increases toward the end of the twenty-first century, and the maximum warming occurs in the high-emission SSP5-8.5 scenario. The warming over Africa for the near (long)-term period is projected to be $1.2{ }^{\circ} \mathrm{C}\left(1.4{ }^{\circ} \mathrm{C}\right), 1.5^{\circ} \mathrm{C}\left(2.3{ }^{\circ} \mathrm{C}\right)$, and $1.8^{\circ} \mathrm{C}$ $\left(4.4^{\circ} \mathrm{C}\right)$ under SSP1-2.6, SSP2-4.5, and SSP5-8.5, respectively (Table 2 and Fig. 5). The $66 \%$ likely range for warming in the near (long) term is $1.0-1.7{ }^{\circ} \mathrm{C}\left(0.9-1.8^{\circ} \mathrm{C}\right)$, $1.2-1.8{ }^{\circ} \mathrm{C}\left(1.8-3.0^{\circ} \mathrm{C}\right)$, and $1.6-2.3{ }^{\circ} \mathrm{C}\left(3.2-5.5^{\circ} \mathrm{C}\right)$, under SSP1-2.6, SSP2-4.5, and SSP5-8.5, respectively (Table 2 and Fig. 5). The full range of temperature change slightly exceeds the $66 \%$ likely range. A detailed description of temperature trends in the twenty-first century over Africa and its eight subregions is given in Table 3. This shows a significant warming trend over Africa under the SSP1-2.6, SSP2-4.5, and SSP5-8.5 scenarios. During the period 2030-2099, temperature trends over Africa under SSP1-2.6, SSP2-4.5, and SSP5-8.5 are $0.03{ }^{\circ} \mathrm{C}$ decade $^{-1}$, 
Fig. 3 Future changes in mean annual temperature $\left({ }^{\circ} \mathrm{C}\right)$ over Africa under three scenarios (SSP1-2.6, SSP2-4.5, SSP58.5) for the two time periods (2030-2059 and 2070-2099) as compared with the reference period (1981-2010). The backslash and forward slash represent the grid boxes having significant and robust change, respectively, while hatching represents the grid boxes having both significant and robust change. Significance is defined based on a two-tailed Student $t$ test, while robustness is achieved when $66 \%$ of all models project a climate change signal in the same direction
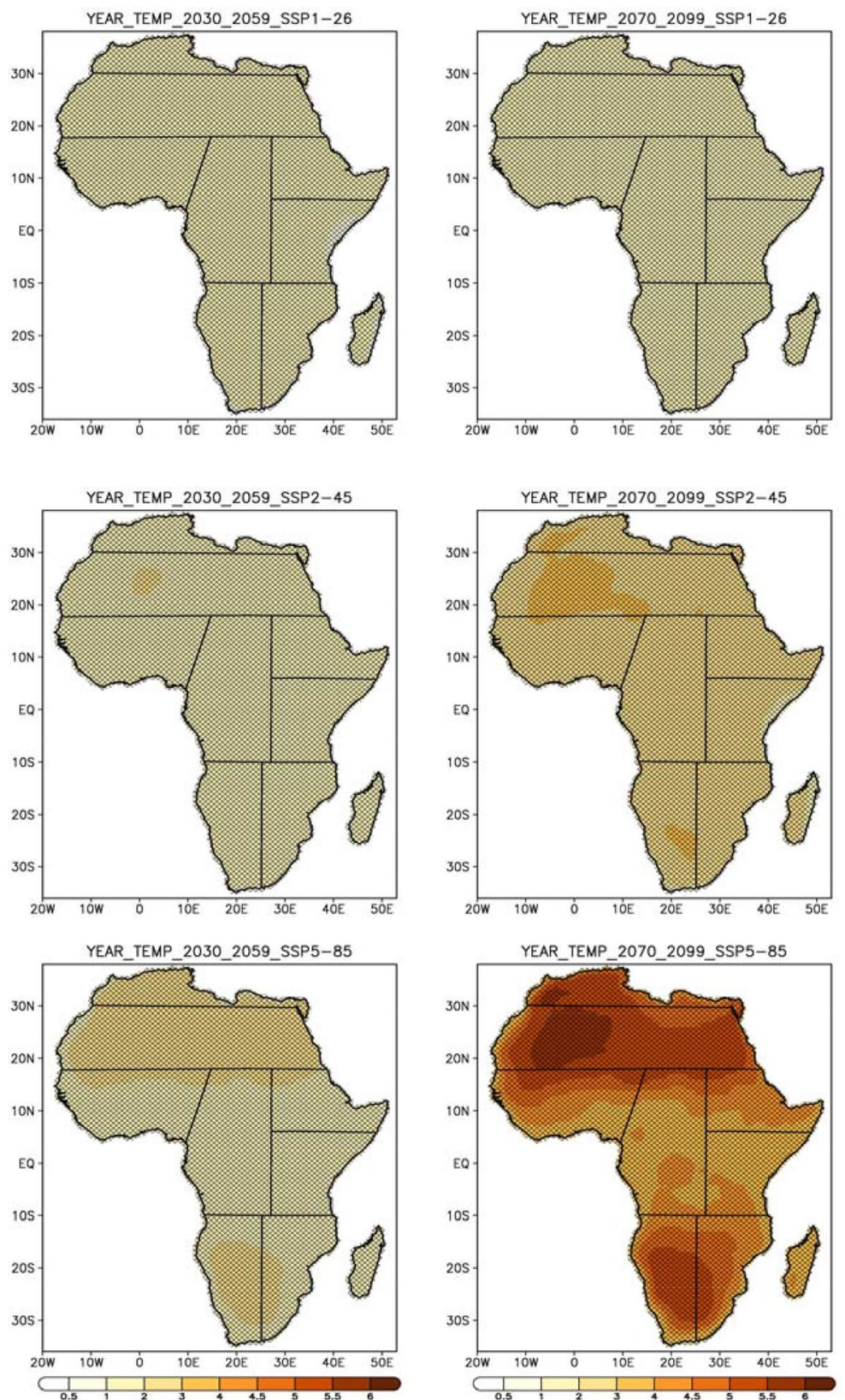

$0.23{ }^{\circ} \mathrm{C}$ decade ${ }^{-1}$, and $0.62{ }^{\circ} \mathrm{C}$ decade $^{-1}$, respectively. These temperature trends are significant at the $99 \%$ confidence level.

The spatial distribution of changes in precipitation over Africa under three future scenarios for the near- and longterm periods is shown in Fig. 4. The projected precipitation shows a robust decrease over northern and southern Africa, with increases over Central Africa during both future periods. For the near (long)-term period, projected changes in precipitation over Africa under SSP1-2.6, SSP2-4.5, and SSP5-8.5 are 6.2 (4.8)\%, $6.8(8.5) \%$, and $9.5(15.2) \%$, respectively, while the $66 \%$ likely range of the change in precipitation over Africa for the near (long)term period is $0.1-14 \%$ ( -4.3 to $12.0 \%), 1.1-17 \%$ ( -0.6 to $18.6 \%)$, and $0.5-28.4 \%$ (1.0-65.4\%) for SSP1-2.6, SSP24.5, and SSP5-8.5, respectively (Table 2 and Fig. 6).

These changes in precipitation over Africa during the twenty-first century show large variability. The areaaveraged values of projected precipitation change over the entire African continent do not realistically represent projected precipitation change over different subregions. Therefore, we examined temperature and precipitation changes over each of the eight subregions of Africa (see Fig. 1). 
Fig. 4 Same as Fig. 3, except showing relative change in precipitation (\%) over Africa
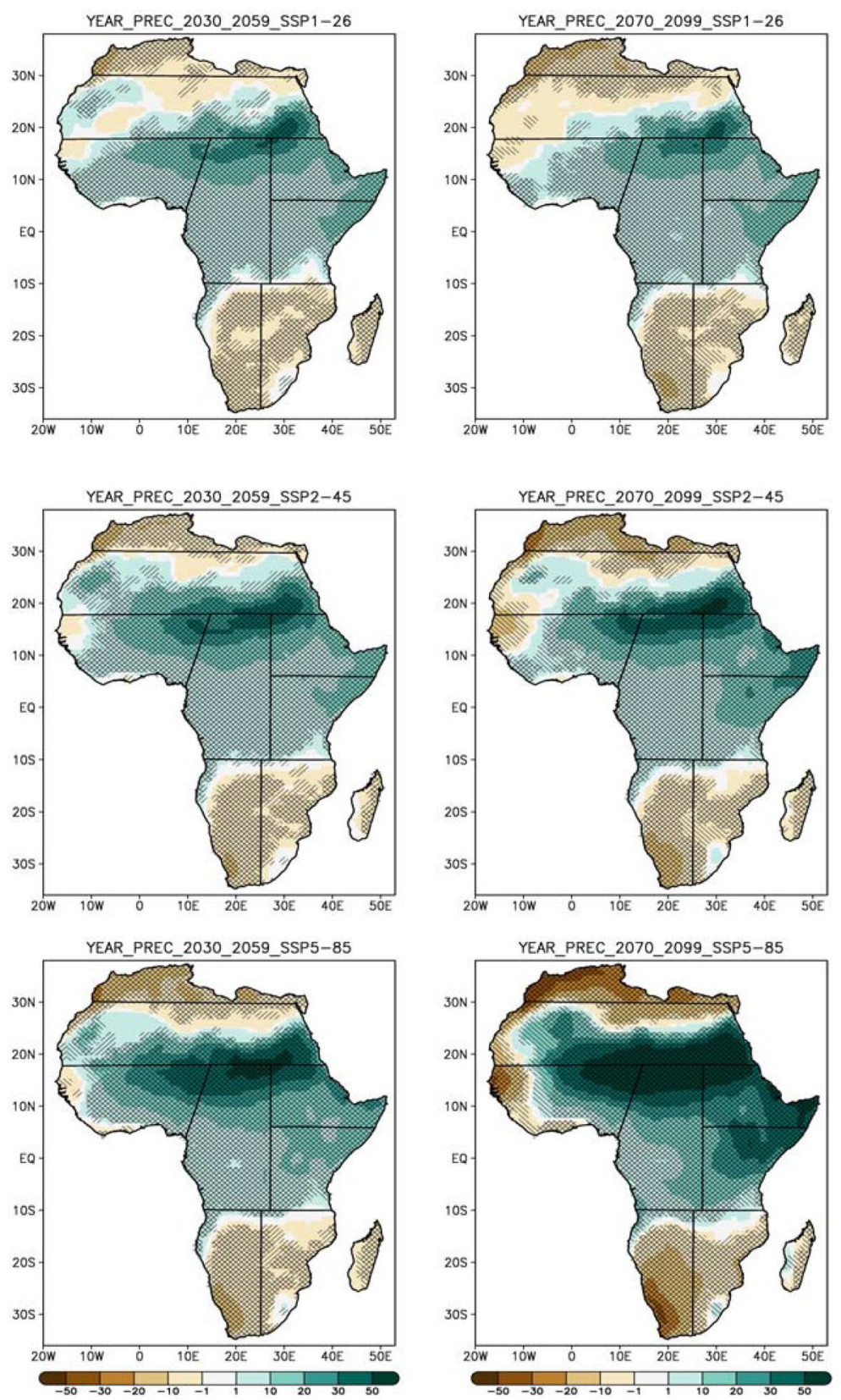

\subsubsection{North Africa (NAF)}

The Mediterranean and adjacent NAF region is one of the hotspots for climate change (Giorgi and Lionello 2008). The CMIP6 models also project continuous warming over NAF during the twenty-first century (Fig. 7). The increasing trend in temperature over NAF under SSP1-2.6, SSP2-4.5, and SSP5-8.5 is projected to be $0.04{ }^{\circ} \mathrm{C}$ decade ${ }^{-1}, 0.26{ }^{\circ} \mathrm{C}$ dec$\mathrm{ade}^{-1}$, and $0.69^{\circ} \mathrm{C}$ decade $^{-1}$, respectively (Table 3 ), and the projected temperature change for the near (long)-term period under SSP1-2.6, SSP2-4.5, and SSP5-8.5 is $1.6(1.7)^{\circ} \mathrm{C}, 1.8$ (2.7) ${ }^{\circ} \mathrm{C}$, and $2.2(5.0){ }^{\circ} \mathrm{C}$, respectively (Fig. 5). The corresponding $66 \%$ likely range of projected warming over NAF for the near (long)-term period is $1.2-2.1{ }^{\circ} \mathrm{C}\left(1.2-2.4{ }^{\circ} \mathrm{C}\right)$, $1.4-2.5{ }^{\circ} \mathrm{C}\left(2.3-3.6{ }^{\circ} \mathrm{C}\right)$, and $1.8-2.9^{\circ} \mathrm{C}\left(4.1-6.0^{\circ} \mathrm{C}\right)$ under SSP1-2.6, SSP2-4.5, and SSP5-8.5, respectively (Fig. 5). A robust reduction in precipitation is also projected for this region during the twenty-first century (Fig. 8, Table 3). On the other hand, median precipitation over NAF is projected to decrease by $-4.8(-9.4) \%,-7.6(-13.6) \%$, and -12.7 (-23.1)\% under SSP1-2.6, SSP2-4.5, and SSP5-8.5, respectively, for the near (long)-term period (Fig. 6). The associated $66 \%$ likely range of precipitation change is -13.1 to $-0.7 \%$ ( -17.2 to $-3.0 \%),-14.8$ to $-1.5 \%$ ( -22.9 to $-4.5 \%$ ), and -18.3 to $-5.7 \%(-36.1$ to $-15.3 \%)$ under SSP1-2.6, SSP2-4.5, and SSP5-8.5, respectively (Fig. 6). 
Table 2 Future changes in mean annual temperature $\left({ }^{\circ} \mathrm{C}\right)$ and precipitation $(\%)$ over Africa for two future time slices (2030-2059 and 20702099) with reference to the base period (1981-2010)

\begin{tabular}{|c|c|c|c|c|c|c|c|c|c|c|}
\hline \multirow[b]{2}{*}{ Scenario } & \multicolumn{5}{|c|}{ 2030-2059 } & \multicolumn{5}{|c|}{ 2070-2099 } \\
\hline & Median & LMV & HMV & $66 \%$ LMV & $66 \% \mathrm{HMV}$ & Median & LMV & HMV & $66 \%$ LMV & $66 \% \mathrm{HMV}$ \\
\hline \multicolumn{11}{|l|}{ Temperature } \\
\hline SSP1-2.6 & 1.24 & 0.76 & 2.02 & 0.96 & 1.70 & 1.39 & 0.74 & 2.38 & 0.93 & 1.85 \\
\hline SSP2-4.5 & 1.46 & 1.03 & 2.29 & 1.22 & 1.76 & 2.32 & 1.78 & 3.81 & 1.84 & 2.98 \\
\hline SSP5-8.5 & 1.77 & 1.08 & 2.65 & 1.58 & 2.29 & 4.36 & 2.90 & 6.37 & 3.23 & 5.51 \\
\hline \multicolumn{11}{|l|}{ Precipitation } \\
\hline SSP1-2.6 & 6.19 & -5.20 & 20.71 & 0.05 & 13.98 & 4.82 & -9.12 & 20.02 & -4.26 & 11.95 \\
\hline SSP2-4.5 & 6.81 & -10.29 & 27.58 & 1.13 & 17.03 & 8.52 & -9.73 & 45.00 & -0.56 & 18.55 \\
\hline SSP5-8.5 & 9.47 & -4.87 & 47.08 & 0.46 & 28.41 & 15.24 & -7.80 & 200.33 & 1.00 & 65.36 \\
\hline
\end{tabular}

The lower median value (LMV) and higher median value (HMV) represent the full range, while 66\% LMV and 66\% HMV represent the 66\% likely range for models used in this study
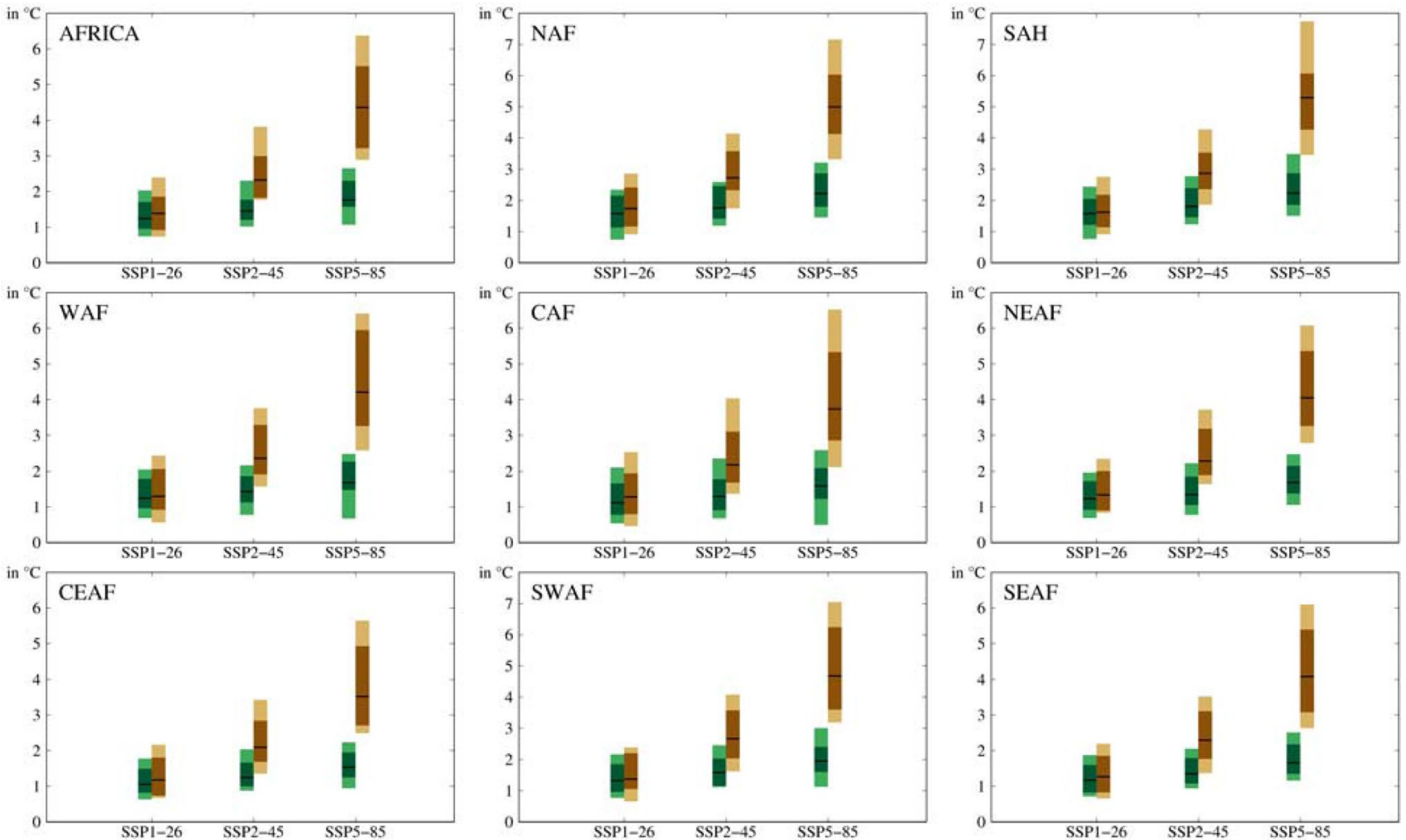

Fig. 5 Projected changes in annual temperature $\left({ }^{\circ} \mathrm{C}\right)$ spatially averaged over the eight regions, as well as over entire Africa. Green and brown bars represent the results for the near term (2030-2059) and long term (2070-2099), respectively, for the three scenarios (SSP1-
2.6, SSP2-4.5, SSP5-8.5). The length of the bars shows full ranges (results from all the models), and the darker color shows likely ranges (66\% of all projected changes are within this range)

\subsubsection{Sahara (SAH)}

The SAH region in Africa is among the hottest and driest places in the Northern Hemisphere (Djili and Hamdi-Aissa 2018). Projections indicate continuous warming over SAH during the twenty-first century (Fig. 7). The increasing trend in temperature over SAH under SSP1-2.6, SSP2-4.5, and SSP5-8.5 is projected to be $0.03{ }^{\circ} \mathrm{C}$ decade ${ }^{-1}, 0.27{ }^{\circ} \mathrm{C} \mathrm{dec}$ ade $^{-1}$, and $0.74{ }^{\circ} \mathrm{C}$ decade $^{-1}$, respectively (Table 3). Projected median temperatures under SSP1-2.6, SSP2-4.5, and SSP5-8.5 increase by $1.6(1.6){ }^{\circ} \mathrm{C}, 1.8(2.9){ }^{\circ} \mathrm{C}$, and 2.2 (5.3) ${ }^{\circ} \mathrm{C}$ for the near (long)-term period, respectively (Fig. 5). 
Table 3 Projected trends in the mean annual temperature $\left({ }^{\circ} \mathrm{C}\right)$ and precipitation $(\%)$ decade $^{-1}$ for the period 2030-2099

\begin{tabular}{lcrrrrrrrr}
\hline Scenario & AFRICA & NAF & \multicolumn{1}{l}{ SAH } & WAF & CAF & CEAF & NEAF & SWAF & SEAF \\
\hline Temperature & & & & & & & & & \\
SSP1-2.6 & $\mathbf{0 . 0 3}$ & $\mathbf{0 . 0 4}$ & $\mathbf{0 . 0 3}$ & $\mathbf{0 . 0 4}$ & $\mathbf{0 . 0 5}$ & $\mathbf{0 . 0 3}$ & $\mathbf{0 . 0 4}$ & $\mathbf{0 . 0 4}$ & $\mathbf{0 . 0 4}$ \\
SSP2-4.5 & $\mathbf{0 . 2 3}$ & $\mathbf{0 . 2 6}$ & $\mathbf{0 . 2 7}$ & $\mathbf{0 . 2 4}$ & $\mathbf{0 . 2 3}$ & $\mathbf{0 . 2 2}$ & $\mathbf{0 . 2 3}$ & $\mathbf{0 . 2 7}$ & $\mathbf{0 . 2 3}$ \\
SSP5-8.5 & $\mathbf{0 . 6 2}$ & $\mathbf{0 . 6 9}$ & $\mathbf{0 . 7 4}$ & $\mathbf{0 . 6 0}$ & $\mathbf{0 . 5 4}$ & $\mathbf{0 . 4 9}$ & $\mathbf{0 . 5 7}$ & $\mathbf{0 . 6 8}$ & $\mathbf{0 . 5 9}$ \\
Precipitation & & & & & & & & & \\
SSP1-2.6 & -0.04 & $-\mathbf{1 . 0 0}$ & $-\mathbf{0 . 8 9}$ & $-\mathbf{0 . 5 0}$ & -0.07 & $\mathbf{0 . 5 2}$ & -0.10 & $-\mathbf{0 . 3 1}$ & $-\mathbf{0 . 1 5}$ \\
SSP2-4.5 & $\mathbf{0 . 2 3}$ & $-\mathbf{1 . 8 2}$ & $-\mathbf{1 . 2 0}$ & -0.11 & $\mathbf{0 . 5 1}$ & $\mathbf{0 . 7 9}$ & $\mathbf{0 . 7 2}$ & $-\mathbf{0 . 2 4}$ & $-\mathbf{0 . 2 5}$ \\
SSP5-8.5 & $\mathbf{0 . 6 6}$ & $-\mathbf{4 . 1 1}$ & $\mathbf{1 . 6 9}$ & $-\mathbf{0 . 2 4}$ & $\mathbf{1 . 4 3}$ & $\mathbf{2 . 6 7}$ & $\mathbf{0 . 7 2}$ & $\mathbf{- 0 . 8 5}$ & $-\mathbf{0 . 3 4}$ \\
\hline
\end{tabular}

The trends that are significant at the $99 \%$ confidence level are shown in bold
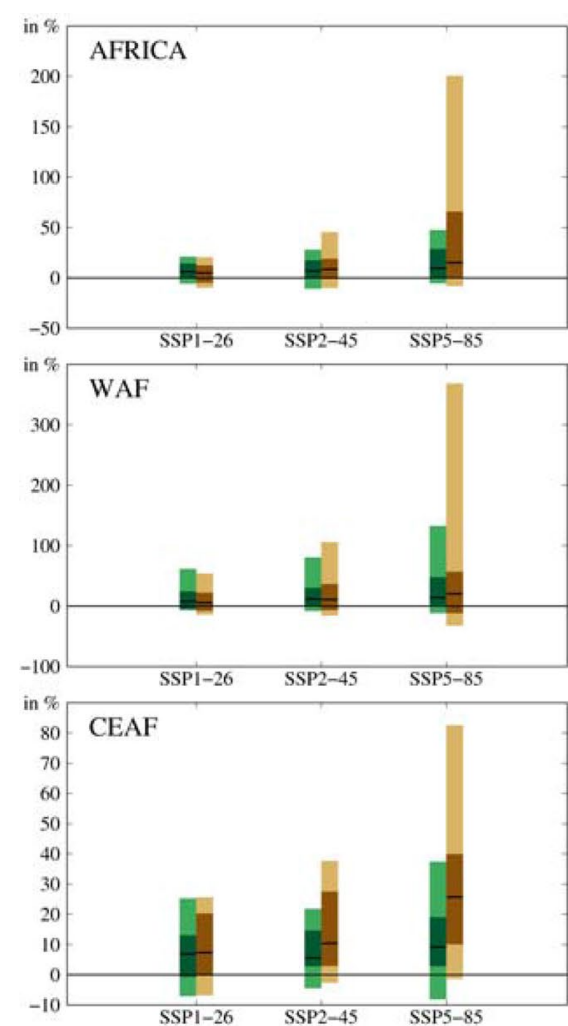
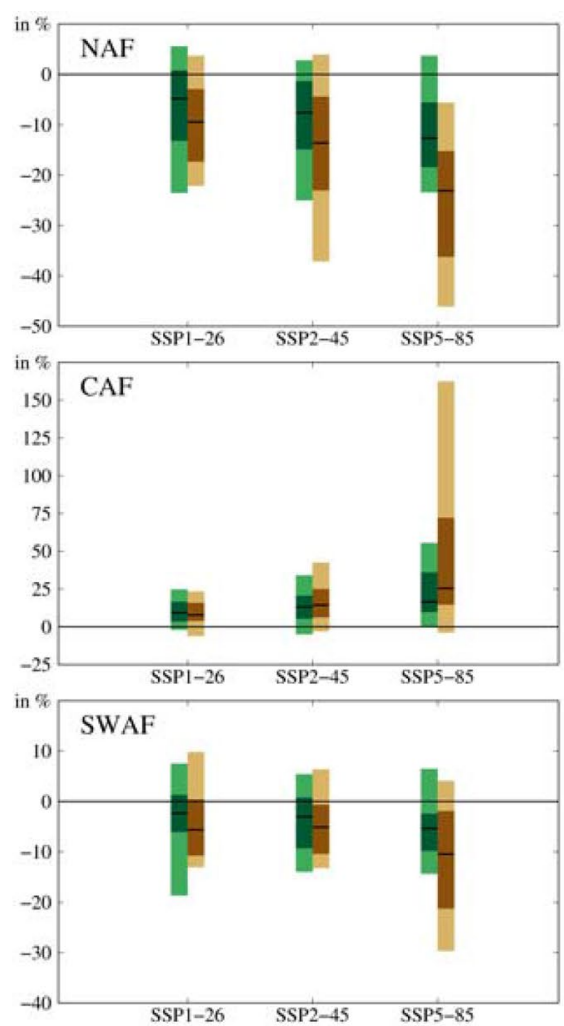
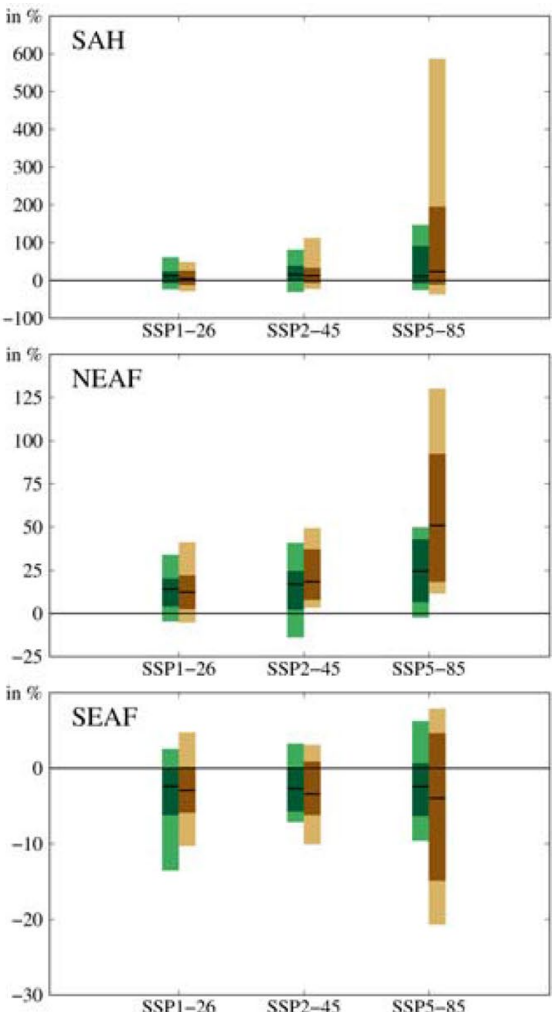

Fig. 6 Same as Fig. 5, except showing changes in annual precipitation (\%)

The $66 \%$ likely range of projected warming over SAH for the near (long)-term period is $1.2-2.0^{\circ} \mathrm{C}\left(1.1-2.2{ }^{\circ} \mathrm{C}\right)$, $1.5-2.4{ }^{\circ} \mathrm{C}\left(2.4-3.5^{\circ} \mathrm{C}\right)$, and $1.9-2.9^{\circ} \mathrm{C}\left(4.3-6.1^{\circ} \mathrm{C}\right)$ under SSP1-2.6, SSP2-4.5, and SSP5-8.5, respectively (Fig. 5). This region is also projected to experience strong interannual variability in precipitation in the twenty-first century (Fig. 8). However, for the high-emission scenario SSP58.5 , precipitation increases toward the end of the twentyfirst century, and the projected precipitation change under SSP1-2.6, SSP2-4.5, and SSP5-8.5 is $12.3(4.9) \%, 15.6$ (12.0)\%, and 11.3 (23.9)\%, respectively, for the near (long)term period (Figs. 6 and 8). Under the same scenarios, the associated $66 \%$ likely range of precipitation change is -5.7 to $22.7 \%$ ( -10.9 to $24.7 \%$ ), -0.3 to $37.8 \%$ ( -5.9 to $32.4 \%$ ), and -6.1 to $89.7 \%$ (-9.9 to $194.2 \%$ ), respectively (Fig. 6).

\subsubsection{West Africa (WAF)}

The WAF region climate is mainly influenced by the West African monsoon system. In a recent study (Wang et al. 2020), it was found that CMIP6 models are better able to simulate global monsoon intensity and precipitation than CMIP5 models. This finding also holds for the WAF monsoon, although common biases and large intermodal spreads persist. The WAF region also shows continuous warming during the twenty-first century (Fig. 7). The increasing trend 


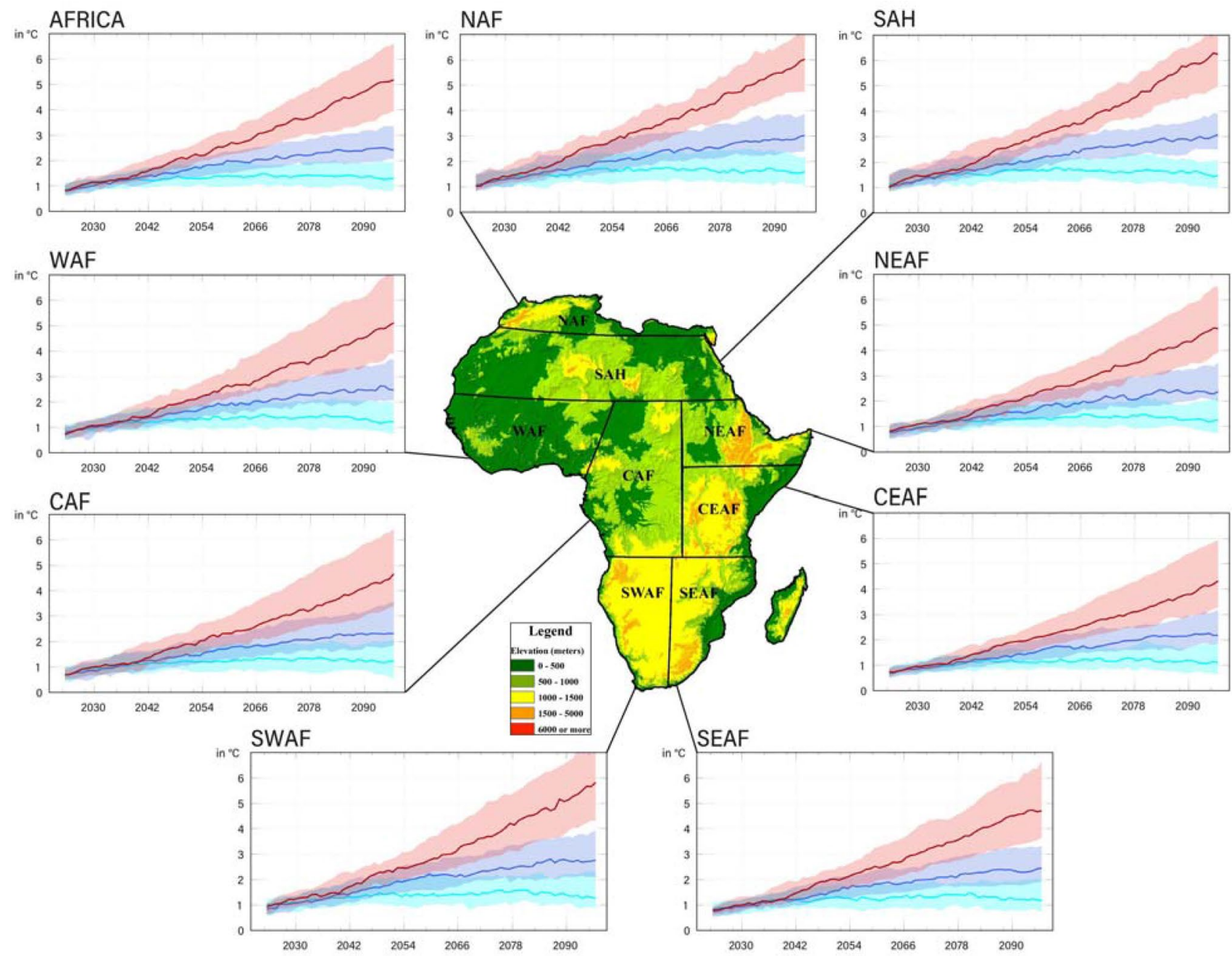

Fig. 7 Area-averaged changes in temperature $\left({ }^{\circ} \mathrm{C}\right)$ for the eight regions and for the entire Africa during the twenty-first century. Green, blue, and red curves represent the median values for SSP1-2.6, SSP2-4.5, and SSP5-8.5, respectively, and the shaded areas around

in temperature over WAF under SSP1-2.6, SSP2-4.5, and SSP5-8.5 is projected to be $0.04{ }^{\circ} \mathrm{C}$ decade ${ }^{-1}, 0.24{ }^{\circ} \mathrm{C} \mathrm{dec}-$ ade $^{-1}$, and $0.6{ }^{\circ} \mathrm{C}$ decade $^{-1}$, respectively (Table 3), with projected warming values of $1.2(1.3){ }^{\circ} \mathrm{C}, 1.4(2.4){ }^{\circ} \mathrm{C}$, and 1.7 (4.2) ${ }^{\circ} \mathrm{C}$, respectively, for the near (long)-term period (Fig. 5). The $66 \%$ likely range of projected warming over WAF for the near (long) term is $1.0-1.8^{\circ} \mathrm{C}\left(0.9-2.0^{\circ} \mathrm{C}\right)$, $1.1-1.8{ }^{\circ} \mathrm{C}\left(1.9-3.3{ }^{\circ} \mathrm{C}\right)$, and $1.5-2.3{ }^{\circ} \mathrm{C}\left(3.3-5.9{ }^{\circ} \mathrm{C}\right)$, respectively, under the same scenarios (Fig. 5). For precipitation, this region also shows a large ensemble spread as well as interannual variability during the twenty-first century, with no clear trend (Fig. 8). The projected changes in precipitation under SSP1-2.6, SSP2-4.5, and SSP5-8.5 are $8.1(5.7) \%, 11.8(10.7) \%$, and $14.2(20.7) \%$, respectively, for the near (long)-term period (Fig. 6). The associated 66\% likely range of precipitation change is -3.6 to $23.5 \%(-6.8$ each of the curves represent the likely range $(66 \%$ of the projected changes). The curves are obtained by taking the difference of each future year with respect to the average from the historical period (1981-2010), and then taking the 7-year running average afterward

to $21.4 \%$ ), 0.7 to $29.6 \%$ ( -5.7 to $35.9 \%$ ), and 2.3 to $47.3 \%$ ( -10.7 to $56.2 \%$ ) under SSP1-2.6, SSP2-4.5, and SSP5-8.5, respectively (Fig. 6).

\subsubsection{Central Africa (CAF)}

A continuous increase in warming is also shown over the CAF region during the twenty-first century (Fig. 7). The increasing trend in temperature over CAF under SSP1-2.6, SSP2-4.5, and SSP5-8.5 is projected to be $0.05{ }^{\circ} \mathrm{C}$ decade $^{-1}, 0.23{ }^{\circ} \mathrm{C}$ decade ${ }^{-1}$, and $0.54{ }^{\circ} \mathrm{C}$ decade ${ }^{-1}$, respectively (Table 3), while the projected increase in temperature is 1.1 (1.3) ${ }^{\circ} \mathrm{C}, 1.3(2.2){ }^{\circ} \mathrm{C}$, and $1.6(3.7){ }^{\circ} \mathrm{C}$, respectively, for the near (long)-term period (Fig. 5). The $66 \%$ likely range of the projected warming over NAF for the near (long) term is $0.8-1.6{ }^{\circ} \mathrm{C}\left(0.8-1.9{ }^{\circ} \mathrm{C}\right), 0.9-1.8{ }^{\circ} \mathrm{C}\left(1.7-3.1^{\circ} \mathrm{C}\right)$, and 


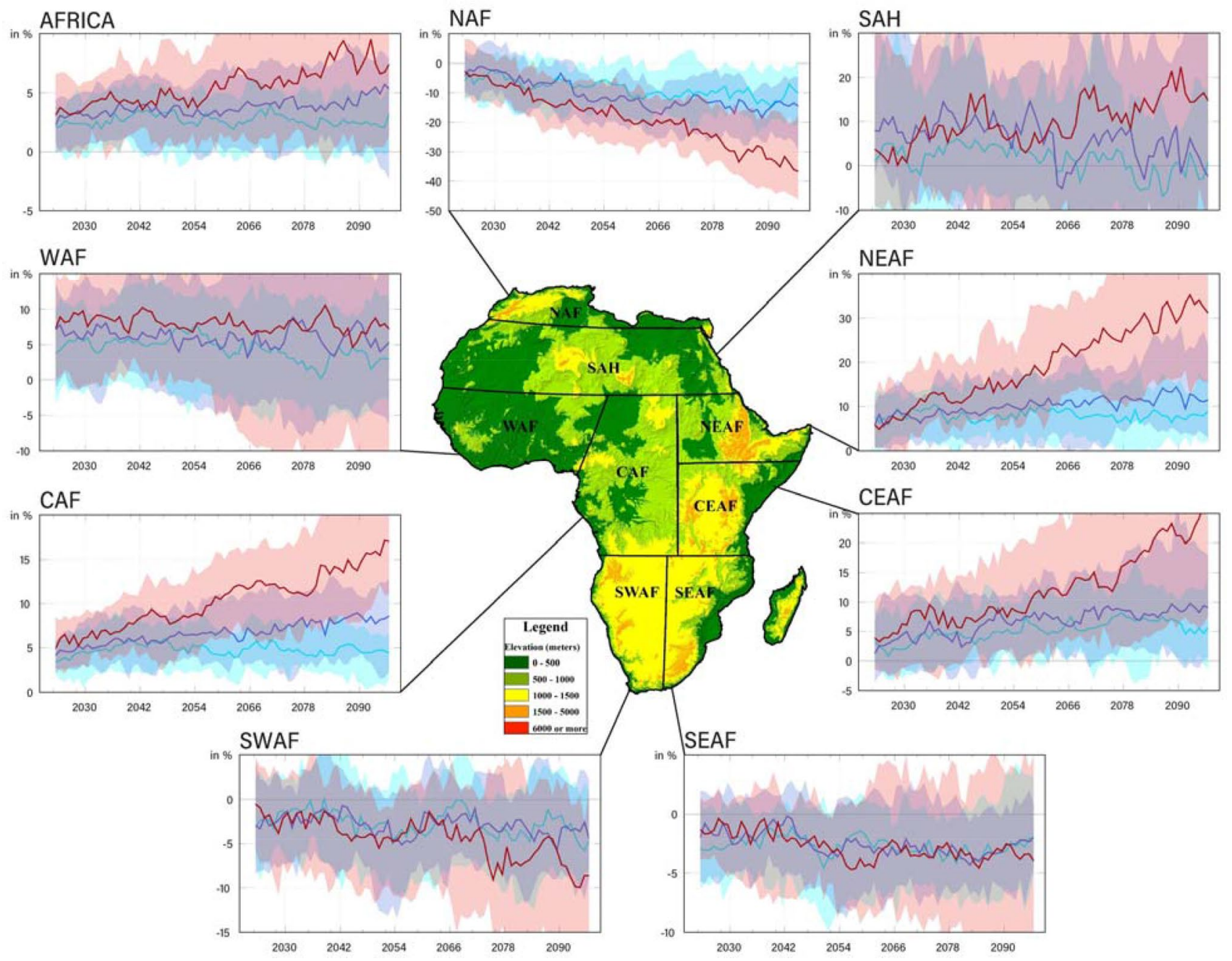

Fig. 8 Same as Fig. 7 except showing precipitation change (\%) for the twenty-first century

1.2-2.1 ${ }^{\circ} \mathrm{C}\left(2.8-5.3{ }^{\circ} \mathrm{C}\right)$ under SSP1-2.6, SSP2-4.5, and SSP5-8.5, respectively (Fig. 5). For precipitation, the region shows an increasing trend during the SSP5-85 scenario, while only weakly increasing trends are evident under SSP24.5 or SSP1-2.6 (Fig. 8). For the near (long)-term period, the precipitation is projected to increase by 9.4 (7.9)\%, 13.2 (14.4)\%, and 16.6 (25.5)\% under SSP1-2.6, SSP2-4.5, and SSP5-8.5, respectively, with the associated $66 \%$ likely range of precipitation change values being 3.8-16.3\% (4.1-15.6\%), $5.6-20.4 \%$ (6.5-24.7\%), and 10.0-35.8\% (15.0-71.8\%), respectively (Fig. 6).

\subsubsection{North East Africa (NEAF)}

For the NEAF region as well, a continuous increase in warming is observed during the twenty-first century (Fig. 7). The increasing trend in temperature over NEAF under SSP1-2.6, SSP2-4.5, and SSP5-8.5 is projected to be
$0.04{ }^{\circ} \mathrm{C}$ decade ${ }^{-1}, 0.23{ }^{\circ} \mathrm{C}$ decade $^{-1}$, and $0.57{ }^{\circ} \mathrm{C} \mathrm{decade}^{-1}$, respectively (Table 3 ). For the near (long)-term period, projected warming under SSP1-2.6, SSP2-4.5, and SSP58.5 is $1.2(1.3){ }^{\circ} \mathrm{C}, 1.3(2.3){ }^{\circ} \mathrm{C}$, and $1.7(4.1){ }^{\circ} \mathrm{C}$, respectively, while the $66 \%$ likely range of projected warming is $0.9-1.7{ }^{\circ} \mathrm{C}\left(0.9-2.0{ }^{\circ} \mathrm{C}\right), 1.1-1.8{ }^{\circ} \mathrm{C}\left(1.9-3.2{ }^{\circ} \mathrm{C}\right)$, and $1.4-2.1{ }^{\circ} \mathrm{C}\left(3.3-5.3{ }^{\circ} \mathrm{C}\right)$, respectively (Fig. 5). This region also shows an increasing precipitation trend in SSP5-8.5, while SSP2-4.5 and SSP1-2.6 do not show a uniform trend during this period (Fig. 8). Even so, the region shows a robust increase in future precipitation during the twentyfirst century (Fig. 6, Table 3). The projected precipitation increases are $14.2(12.3) \%, 16.9(18.4) \%$, and $24.5(51.0) \%$ under SSP1-2.6, SSP2-4.5, and SSP5-8.5, respectively, for the near (long)-term period, with the associated 66\% likely range of precipitation change being $4.2-19.9 \%(2.7-21.8 \%)$, 2.4-24.3\% (8.0-36.9\%), and 6.8-42.6\% (18.6-92.2\%), respectively (Fig. 6). 


\subsubsection{Central East Africa (CEAF)}

The CEAF region shows an increase in warming during the twenty-first century (Fig. 7). The increasing trend in temperature over CEAF under SSP1-2.6, SSP2-4.5, and SSP5-8.5 is projected to be $0.03{ }^{\circ} \mathrm{C}$ decade ${ }^{-1}, 0.22{ }^{\circ} \mathrm{C} \mathrm{dec}$ ade $^{-1}$, and $0.49^{\circ} \mathrm{C}$ decade $^{-1}$, respectively (Table 3 ), while the projected increase in temperature values under the same scenarios are $1.1(1.2){ }^{\circ} \mathrm{C}, 1.2(2.1){ }^{\circ} \mathrm{C}$, and 1.5 (3.5) ${ }^{\circ} \mathrm{C}$, respectively, for the near (long)-term period. The $66 \%$ likely range of projected warming over CEAF for the near (long) term is $0.8-1.5{ }^{\circ} \mathrm{C}\left(0.7-1.8^{\circ} \mathrm{C}\right), 1.0-1.6{ }^{\circ} \mathrm{C}$ $\left(1.7-2.8^{\circ} \mathrm{C}\right)$, and $1.3-1.9^{\circ} \mathrm{C}\left(2.7-4.9^{\circ} \mathrm{C}\right)$ under SSP1-2.6, SSP2-4.5, and SSP5-8.5, respectively (Fig. 5). Similar to $\mathrm{CAF}$ and NAEF, the projections show an increasing trend in precipitation over CEAF during the twenty-first century (Fig. 8, Table 3). The projected precipitation increases by $6.9(7.4) \%, 5.5(10.4) \%$, and 9.2 (25.7)\% under SSP12.6, SSP2-4.5, and SSP5-8.5, respectively, for the near (long)-term period, with the associated $66 \%$ likely range of precipitation change being -0.5 to $12.9 \%$ ( -0.2 to $20.1 \%$ ), $2.9-14.5 \%(3.1-27.4 \%)$, and 3.0-18.9\% (10.2-39.7\%), respectively (Fig. 6). Similar future trends in both temperature and precipitation over the subregion were found in CMIP5 (Libanda and Ngonga 2018; Ongoma et al. 2018).

\subsubsection{South West Africa (SWAF)}

The CMIP6 models also project continuous warming over the SWAF region during the twenty-first century (Fig. 7). By analyzing the CMIP5 dataset, Diffenbaugh and Giorgi (2012) also found southern Africa to be one of the hotspots for climate change. The increasing trend in temperature over SWAF under SSP1-2.6, SSP2-4.5, and SSP5-8.5 is projected to be $0.04{ }^{\circ} \mathrm{C}$ decade ${ }^{-1}, 0.27{ }^{\circ} \mathrm{C} \mathrm{dec}-$ ade $^{-1}$, and $0.68{ }^{\circ} \mathrm{C}$ decade $^{-1}$, respectively, during the twenty-first century (Table 3 ). The projected increase in temperature over SWAF under the same scenarios is 1.3 (1.4) ${ }^{\circ} \mathrm{C}, 1.6$ (2.7) ${ }^{\circ} \mathrm{C}$, and $1.9(4.7){ }^{\circ} \mathrm{C}$ for the near (long) term period, while the associated $66 \%$ likely range of this projected warming is $1.0-1.8^{\circ} \mathrm{C}\left(1.1-2.2^{\circ} \mathrm{C}\right), 1.2-2.0^{\circ} \mathrm{C}$ $\left(2.1-3.6^{\circ} \mathrm{C}\right)$, and $1.6-2.4^{\circ} \mathrm{C}\left(3.6-6.2^{\circ} \mathrm{C}\right)$, respectively (Fig. 5). Similar to NAF, this region shows a robust reduction in projected precipitation during the twenty-first century, which is most evident in SSP-8.5 (Fig. 8, Table 3). The projected precipitation decreases by $-2.4(-5.6) \%$, $-3.0(-5.1) \%$, and $-5.4(-10.4) \%$ under SSP1-2.6, SSP24.5 , and SSP5-8.5, respectively, for the near (long)-term period, with the associated $66 \%$ likely range of precipitation change being -6.0 to $-1.2 \%$ ( -10.6 to $0.3 \%),-9.2$ to $0.7 \%$ ( -10.3 to $-0.7 \%)$, and -9.7 to $-2.5 \%(-21.2$ to $-2.0 \%$ ), respectively (Fig. 6).

\subsubsection{South East Africa (SEAF)}

The SEAF region is also projected to undergo continuous warming during the twenty-first century (Fig. 7). This increasing trend in temperature over SEAF under SSP12.6, SSP2-4.5, and SSP5-8.5 is projected to be $0.04{ }^{\circ} \mathrm{C} \mathrm{dec}$ ade $^{-1}, 0.23{ }^{\circ} \mathrm{C}$ decade $^{-1}$, and $0.59^{\circ} \mathrm{C} \mathrm{decade}^{-1}$, respectively (Table 3). The projected temperature over SEAF increases by $1.2(1.3){ }^{\circ} \mathrm{C}, 1.4(2.3){ }^{\circ} \mathrm{C}$, and 1.7 (4.1) ${ }^{\circ} \mathrm{C}$ under SSP12.6, SSP2-4.5, and SSP5-8.5, respectively, for the near (long)-term period, while the $66 \%$ likely range of projected warming is found to be $0.8-1.6^{\circ} \mathrm{C}\left(0.8-1.8^{\circ} \mathrm{C}\right), 1.1-1.8^{\circ} \mathrm{C}$ $\left(1.8-3.1{ }^{\circ} \mathrm{C}\right)$, and $1.4-2.2{ }^{\circ} \mathrm{C}\left(3.2-5.4{ }^{\circ} \mathrm{C}\right)$, respectively (Fig. 5). Similar to SWAF, this region shows a robust reduction in projected precipitation during the twenty-first century (Fig. 8, Table 3). For the near (long)-term period, the precipitation over SEAF is projected to decrease by -2.4 $(-2.9) \%,-2.7(-3.4) \%$, and $-2.4(-4.0) \%$ under SSP1-2.6, SSP2-4.5, and SSP5-8.5, respectively, with the associated $66 \%$ likely range of precipitation change being -6.1 to $0.0 \%$ ( -5.8 to $0.1 \%),-5.6$ to $0.1 \%$ ( -6.1 to $0.8 \%$ ), and -6.3 to $-0.6 \%$ ( -14.8 to $4.6 \%$ ), respectively (Fig. 6).

\subsection{Projected Changes in Temperature and Precipitation During the Boreal Winter Season}

Figure 9 shows the spatial distribution of the changes in boreal winter (DJF) temperature over Africa for two future time slices under the three SSP scenarios, in which warming is seen over the entire African continent. However, the changes in boreal winter temperature are more prominent toward the end of the twenty-first century for the highemission scenario SSP5-8.5. In this case, the northern and southern parts of Africa display enhanced warming relative to the central area. By the end of the twenty-first century, the boreal winter temperature increase (66\% likely range) over Africa is projected to be $1.2{ }^{\circ} \mathrm{C}\left(0.9-1.7^{\circ} \mathrm{C}\right), 2.2^{\circ} \mathrm{C}$ $\left(1.8-2.8{ }^{\circ} \mathrm{C}\right)$, and $4.1{ }^{\circ} \mathrm{C}\left(3.1-5.3{ }^{\circ} \mathrm{C}\right)$ under SSP1-2.6, SSP2-4.5, and SSP5-8.5, respectively. For the eight subregions of Africa (Fig. 1), namely NAF, SAH, WAF, CAF, CEAF, NEAF, SWAF, and SEAF, the temperature increase (66\% likely range) under SSP5-8.5 is projected to be $4.1{ }^{\circ} \mathrm{C}$ (3.2-4.9 $\left.{ }^{\circ} \mathrm{C}\right), 4.4{ }^{\circ} \mathrm{C}\left(3.7-5.5{ }^{\circ} \mathrm{C}\right), 4.3{ }^{\circ} \mathrm{C}\left(3.4-5.8^{\circ} \mathrm{C}\right)$, $3.7^{\circ} \mathrm{C}\left(2.8-5.3^{\circ} \mathrm{C}\right), 3.4^{\circ} \mathrm{C}\left(2.6-4.7^{\circ} \mathrm{C}\right), 4.4^{\circ} \mathrm{C}\left(3.4-5.4{ }^{\circ} \mathrm{C}\right)$, $4.4^{\circ} \mathrm{C}\left(3.4-6.1^{\circ} \mathrm{C}\right)$, and $3.9^{\circ} \mathrm{C}\left(3.0-5.5^{\circ} \mathrm{C}\right)$, respectively.

Figure 10 shows the spatial distribution of future changes in the boreal winter precipitation over Africa for the nearand long-term periods under three SSP scenarios. It shows a strong reduction in this precipitation over northwestern and southwestern Africa, along with a robust increase over the central and northeastern parts. By the end of the twentyfirst century, the winter precipitation (66\% likely range) over 
Fig. 9 Same as Fig. 3, except showing boreal winter temperature change (in ${ }^{\circ} \mathrm{C}$ )
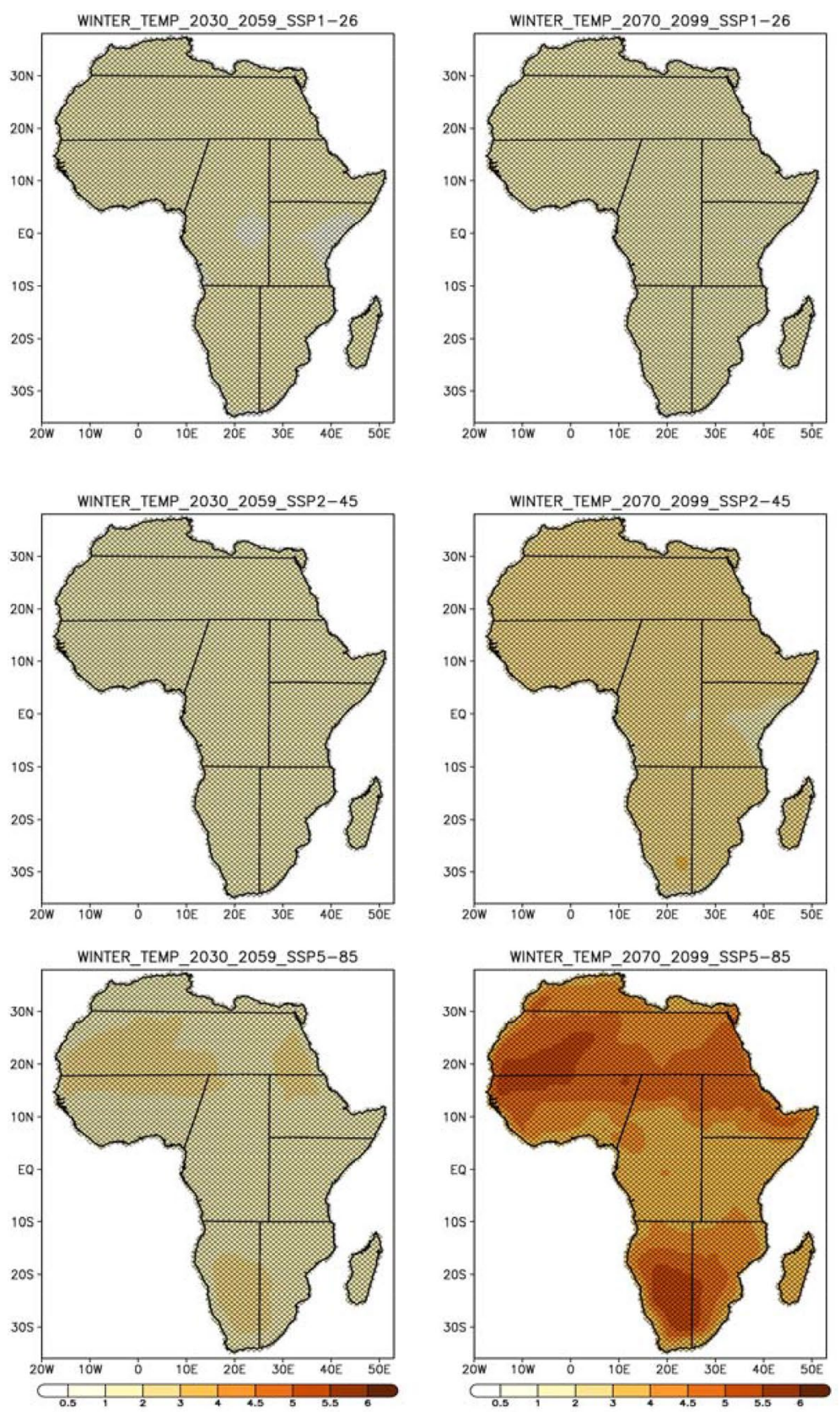

Africa is projected to change by $16.0 \%$ ( -4.4 to $36.5 \%$ ), $19.6 \%$ ( -7.9 to $42.0 \%$ ), and $35.2 \%$ ( -1.0 to $529.2 \%$ ) under SSP1-2.6, SSP2-4.5, and SSP5-8.5, respectively. For the eight subregions, namely NAF, SAH, WAF, CAF, CEAF, NEAF, SWAF, and SEAF, the precipitation (66\% likely range) is projected to change by $-35.0 \%$ ( -42.4 to $-19.2 \%)$, $-2.5 \%$ ( -29.1 to $396.6 \%$ ), $37.5 \%$ ( -10.5 to $162.4 \%$ ), $86.3 \%$ (20.7 to $140.8 \%$ ), $74.1 \%$ (44.8 to $130.0 \%$ ), $139.7 \%$ (27.7 to $360.9 \%),-3.4 \%$ ( -16.9 to $2.2 \%$ ), and $2.1 \%$ ( -10.3 to $8.7 \%$ ), respectively. Not surprisingly, much higher uncertainty in the projected precipitation signal is found over West Africa, where the ensemble shows a very wide likely range.

\subsection{Changes in Temperature and Precipitation Projections for the Boreal Summer Season}

Figure 11 displays changes in temperature during the boreal summer season (JJA) for the near- and long-term periods under the three SSP scenarios. The entire African continent shows warming during this season. The warming is more pronounced in the northern and southwestern parts of Africa toward the end of twenty-first century under the high-emission scenario SSP5-8.5. By the end of twenty-first century, the boreal summer temperature (66\% likely range) over Africa is projected to increase by $1.5^{\circ} \mathrm{C}\left(0.9-2.0^{\circ} \mathrm{C}\right)$, 
Fig. 10 Same as Fig. 4, except showing boreal winter precipitation relative change (in \%)
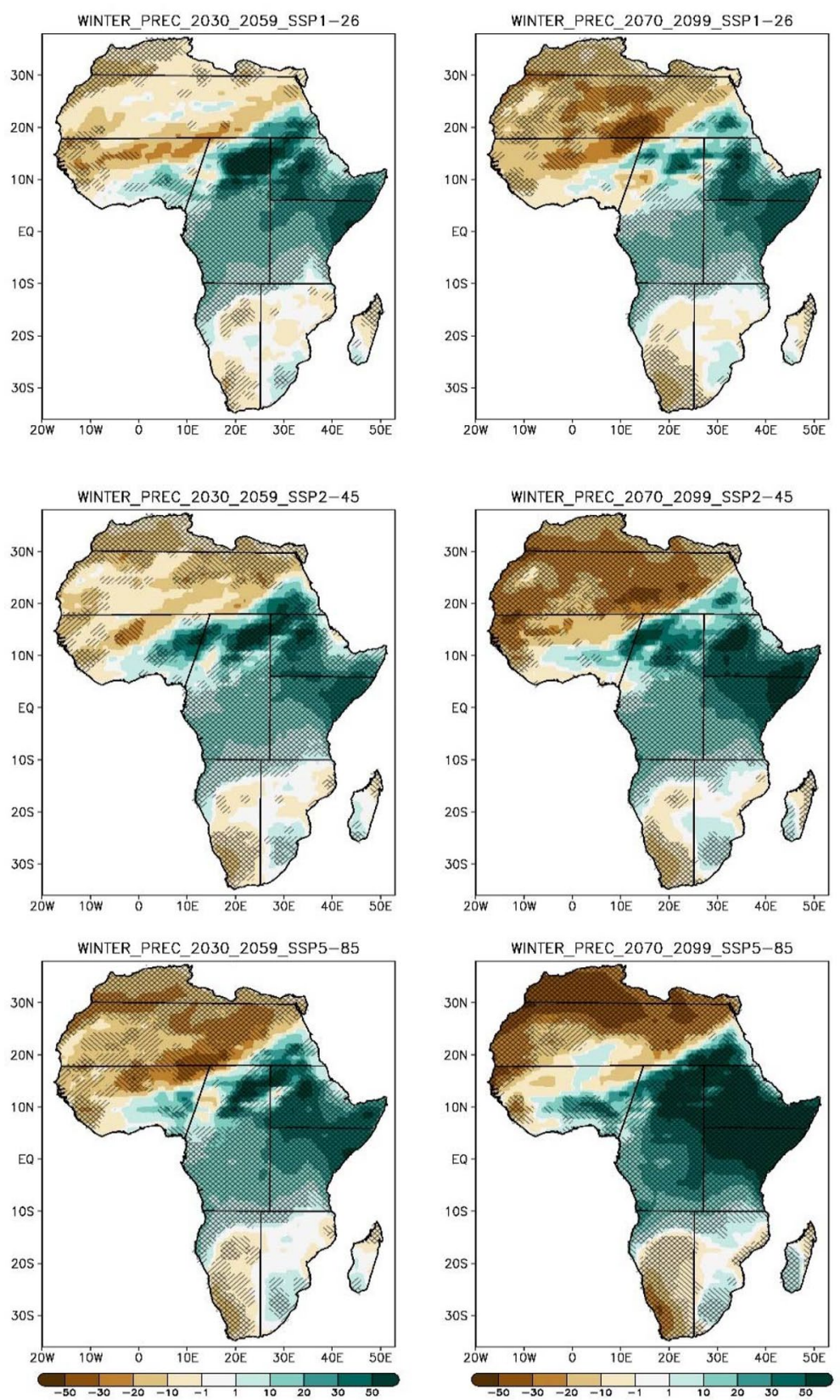

$2.6{ }^{\circ} \mathrm{C}\left(2.0-3.3{ }^{\circ} \mathrm{C}\right)$, and $4.6{ }^{\circ} \mathrm{C}\left(3.4-5.7^{\circ} \mathrm{C}\right)$ under SSP12.6, SSP2-4.5, and SSP5-8.5, respectively. For the eight subregions, namely NAF, SAH, WAF, CAF, CEAF, NEAF, SWAF, and SEAF, the projected boreal summer temperature increase (66\% likely range) under SSP5-8.5 is $6.2^{\circ} \mathrm{C}$ $\left(5.0-7.3{ }^{\circ} \mathrm{C}\right), 6.0{ }^{\circ} \mathrm{C}\left(4.7-6.8^{\circ} \mathrm{C}\right), 3.9{ }^{\circ} \mathrm{C}\left(3.2-5.7{ }^{\circ} \mathrm{C}\right)$, $3.9^{\circ} \mathrm{C}\left(2.9-5.6^{\circ} \mathrm{C}\right), 3.8^{\circ} \mathrm{C}\left(2.9-5.3^{\circ} \mathrm{C}\right), 4.1^{\circ} \mathrm{C}\left(2.9-5.5^{\circ} \mathrm{C}\right)$, $4.6^{\circ} \mathrm{C}\left(3.4-6.0^{\circ} \mathrm{C}\right)$, and $4.1^{\circ} \mathrm{C}\left(2.9-5.2^{\circ} \mathrm{C}\right)$, respectively. During the boreal summer season, the largest warming is projected over the $\mathrm{NAF}\left(>6^{\circ} \mathrm{C}\right)$ and $\mathrm{SAH}\left(>5^{\circ} \mathrm{C}\right)$ regions under the SSP5-8.5 scenario.

The spatial distribution of changes in the boreal summer precipitation over the African continent is shown in
Fig. 12. The precipitation pattern shows a reduction over the northern, northwestern, and southern parts of Africa, along with an increase in the central and adjacent northeastern and northwestern parts, during both the near- and long-term periods under all three scenarios. The projected change in boreal summer precipitation is nearly opposite that of the winter pattern, where the northern parts show much lower precipitation as compared with the southern parts. During boreal summer, southern Africa displays a robust reduction in precipitation, while the northern parts show much less robust signals of reduced precipitation.

The projected changes in boreal summer precipitation are enhanced for the high-emission scenario. By the end 
Fig. 11 Same as Fig. 3, except showing boreal summer temperature change $\left(\right.$ in ${ }^{\circ} \mathrm{C}$ )
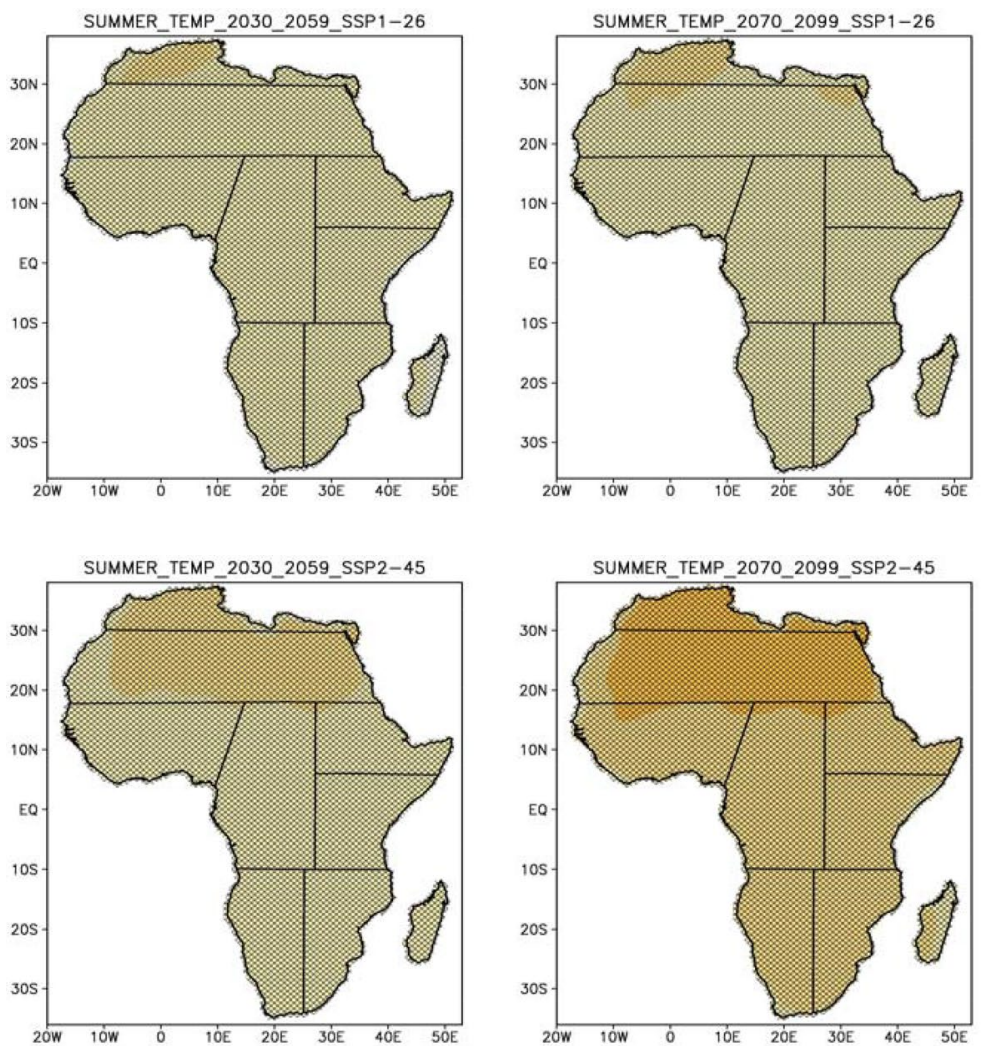

SUMMER_TEMP_2030_2059_SSP5-85

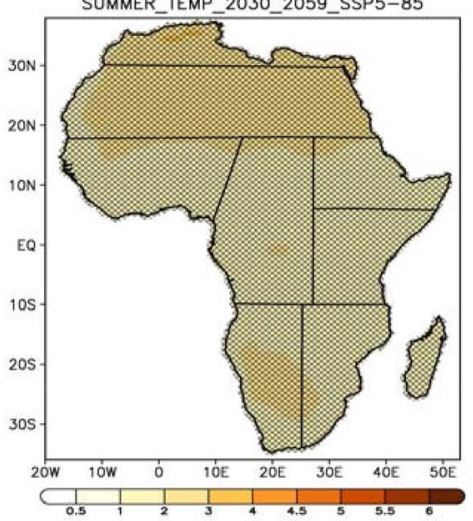

SUMMER_TEMP_2070_2099_SSP5-85

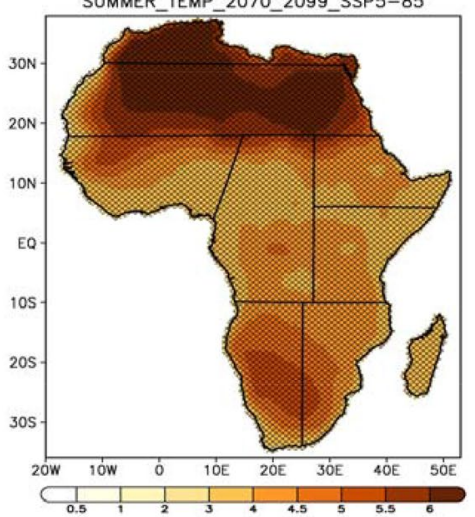

of the twenty-first century, under SSP5-8.5, the boreal summer precipitation (66\% likely range) over the eight subregions, namely NAF, SAH, WAF, CAF, CEAF, NEAF, SWAF, and SEAF, is projected to be $-19.8 \%(-45.3$ to $8.2 \%), 64.4 \%$ (16.9 to $700.1 \%$ ), $14.5 \%$ (-17.6 to $43.0 \%$ ), $27.3 \%$ (4.1 to $63.8 \%), 5.4 \%$ (-12.1 to $45.9 \%), 46.7 \%$ (20.8 to $92.2 \%$ ), $-48.9 \%$ ( -60.7 to $-26.9 \%$ ), and $-30.3 \%$ ( -41.0 to $-14.5 \%)$, respectively. It can be seen that SAH shows large changes in the boreal summer precipitation. This region is very dry, with very low mean annual precipitation. A small increase in the absolute amount of precipitation in any future period can thus result in a large percentage change in precipitation.

\subsection{Differences Between CMIP5- and CMIP6-Projected Signals Over Africa}

We further investigated the difference between the CMIP5 and CMIP6 climate model responses to anthropogenic forcing over Africa. We computed the difference between the projected mean annual temperature for medium (SSP2-4.5 and RCP4.5) and strong (SSP5-8.5 and RCP8.5) scenarios between the median values of the two projects (Fig. 13). For both the scenarios and time periods, the CMIP6 climate models simulate higher temperatures over large parts of Africa. In the Southern Hemisphere, the CMIP6 temperatures are higher than those of the CMIP5 by $1{ }^{\circ} \mathrm{C}$, whereas in the Northern Hemisphere 
Fig. 12 Same as Fig. 4, except showing boreal summer precipitation change $(\%)$
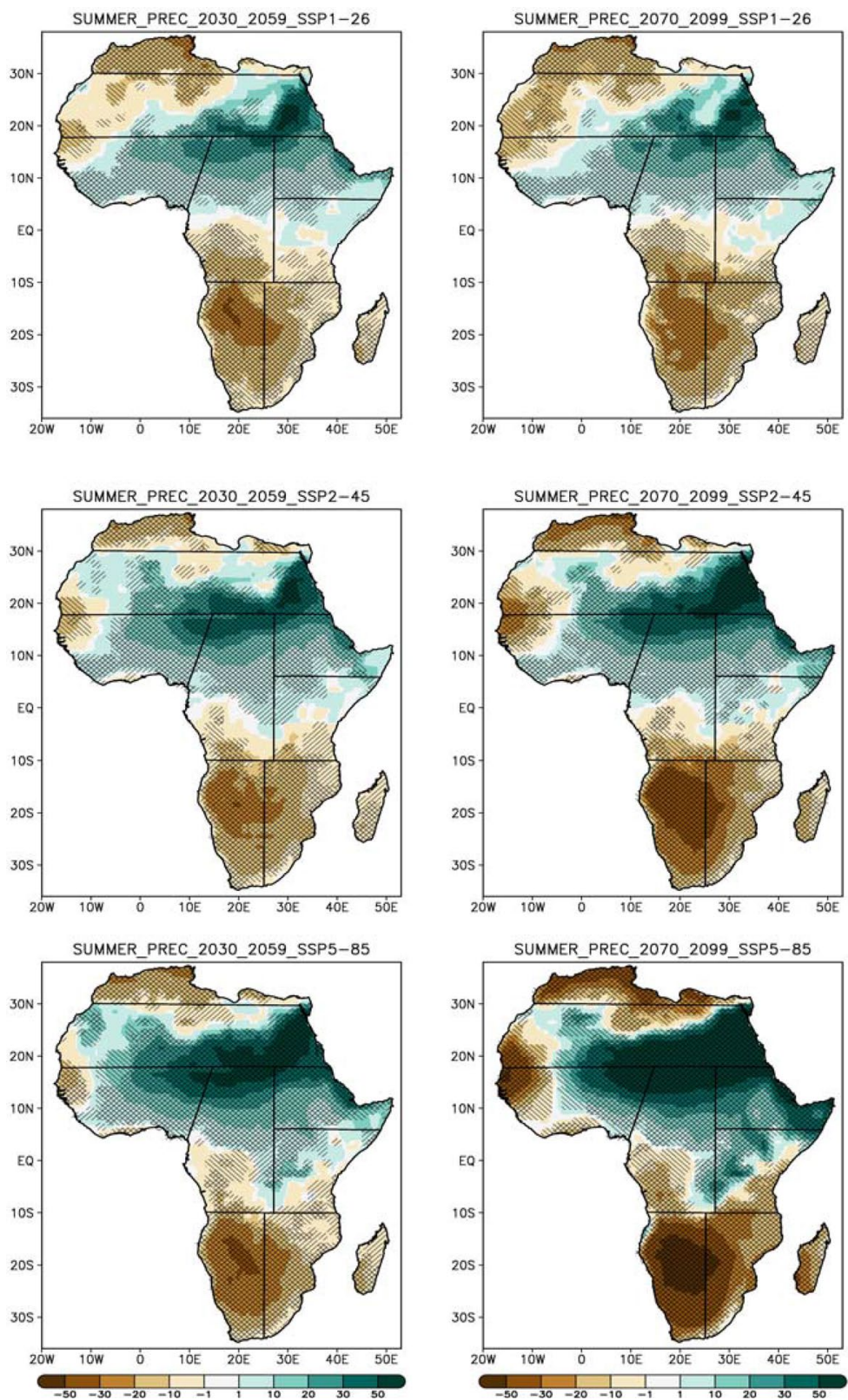

this difference increases to as much as $2.5^{\circ} \mathrm{C}$ over the region surrounding Sudan and Niger. The results for precipitation show a mixed signal which is more or less consistent across both the scenarios and time periods (Fig. 14). The CMIP6 model ensemble projects more precipitation over NAF, SAH, CEAF, and western WAF as compared with CMIP5, whereas CMIP6 projects reduced precipitation over SWAF, CAF, and especially NEAF.

\section{Summary and Conclusions}

We analyzed a multi-model ensemble based on 27 CMIP6 models and examined projected temperature and precipitation changes over Africa in the twenty-first century. These changes were computed for the African continent and its eight subregions during two future time slices (2030-2059 and 2070-2099) relative to the present climate (1981-2010). The CMIP6 multi-model ensemble projected a continuous increase in annual temperature over all of 

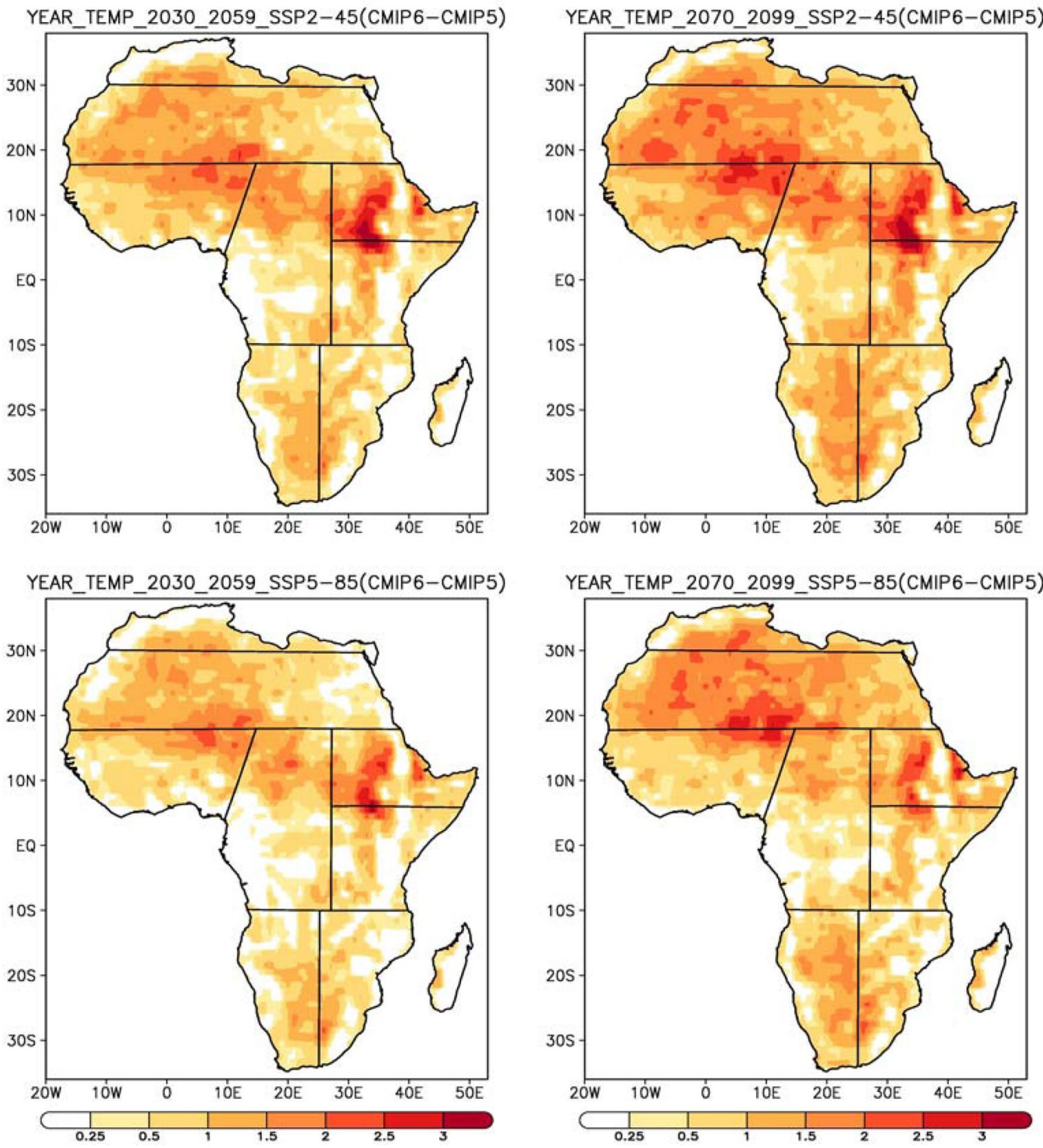

Fig. 13 Difference $\left({ }^{\circ} \mathrm{C}\right)$ in the projected mean annual temperature over Africa between CMIP6 and CMIP5 models. The difference (CMIP6 minus CMIP5) in projected signals is obtained for median

Africa and its eight subregions during the twenty-first century. Over that time, a significant increasing trend (at the 99\% confidence level) in temperature is projected for the three SSP scenarios analyzed in this study (Table 3). The annual temperature over Africa for the near (long)-term period is projected to increase by $1.2{ }^{\circ} \mathrm{C}\left(1.4{ }^{\circ} \mathrm{C}\right), 1.5{ }^{\circ} \mathrm{C}$ $\left(2.3{ }^{\circ} \mathrm{C}\right)$, and $1.8{ }^{\circ} \mathrm{C}\left(4.4{ }^{\circ} \mathrm{C}\right)$ under SSP1-2.6, SSP2-4.5, and SSP5-8.5, respectively. The uncertainty associated with projected temperature over Africa for the near (long)term period under SSP1-2.6, SSP2-4.5, and SSP5-8.5 values for two scenarios (SSP2-4.5 and SSP5-8.5) as well as for two future (near-term and long-term) periods

ranged from 0.8 to $2.0{ }^{\circ} \mathrm{C}\left(0.7-2.4{ }^{\circ} \mathrm{C}\right), 1.0$ to $2.3{ }^{\circ} \mathrm{C}$ $\left(1.8-3.8^{\circ} \mathrm{C}\right)$, and 1.1 to $2.7^{\circ} \mathrm{C}\left(2.9-6.4{ }^{\circ} \mathrm{C}\right)$, respectively.

The projected warming over Africa is not uniform and varies regionally. Furthermore, regional differences in projected warming are more pronounced for the high-emission scenario. Under SSP5-8.5, the largest warming is projected over the Sahara and adjacent parts of northern Africa. A robust increase in warming is also projected for southern Africa during the twenty-first century. In the near (long)term period, the temperature over the eight subregions of 


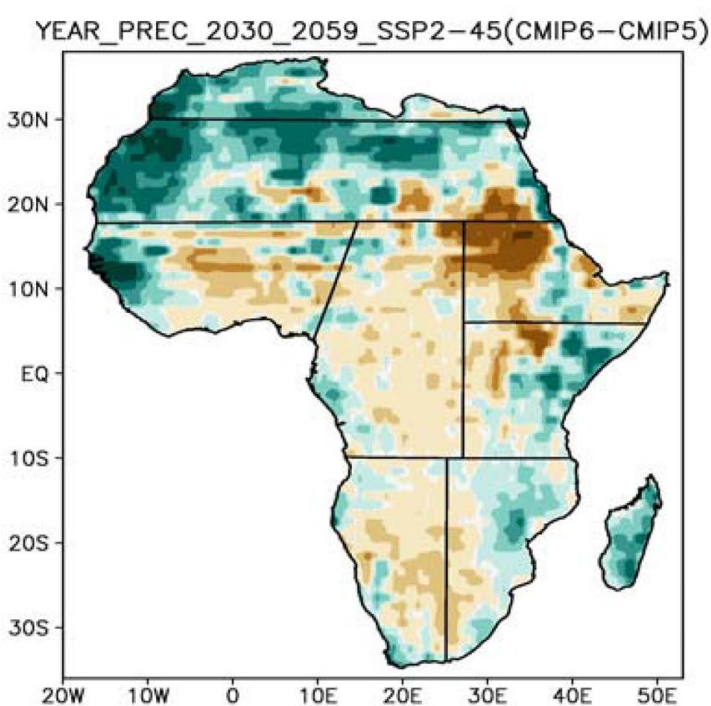

YEAR_PREC_2030_2059_SSP5-85(CMIP6-CMIP5)

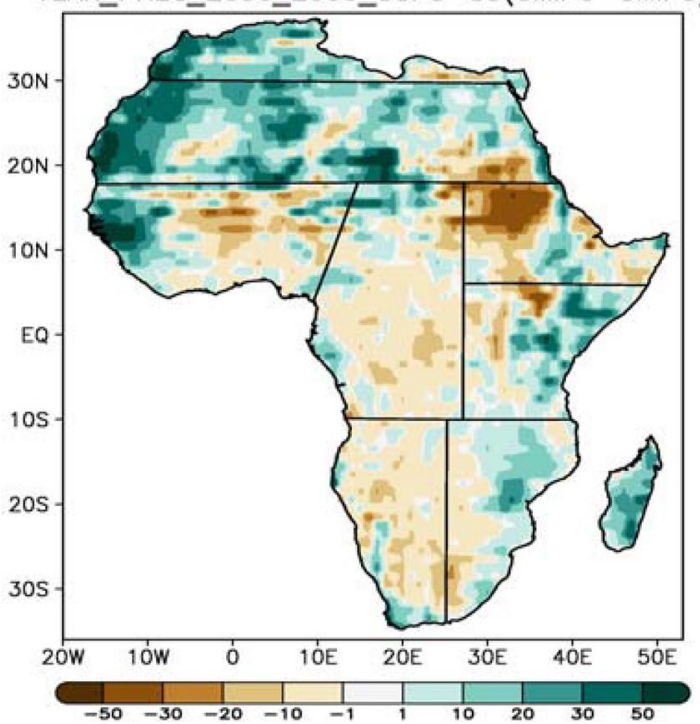

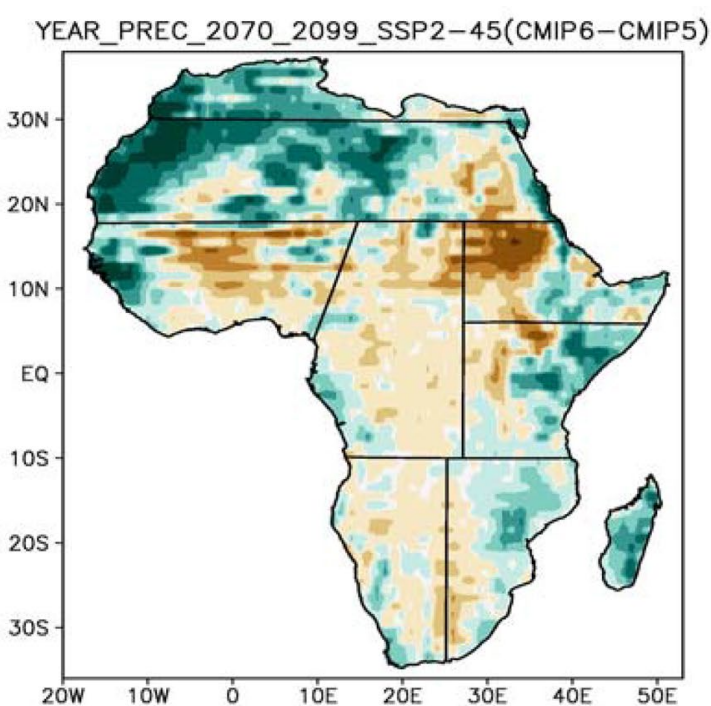

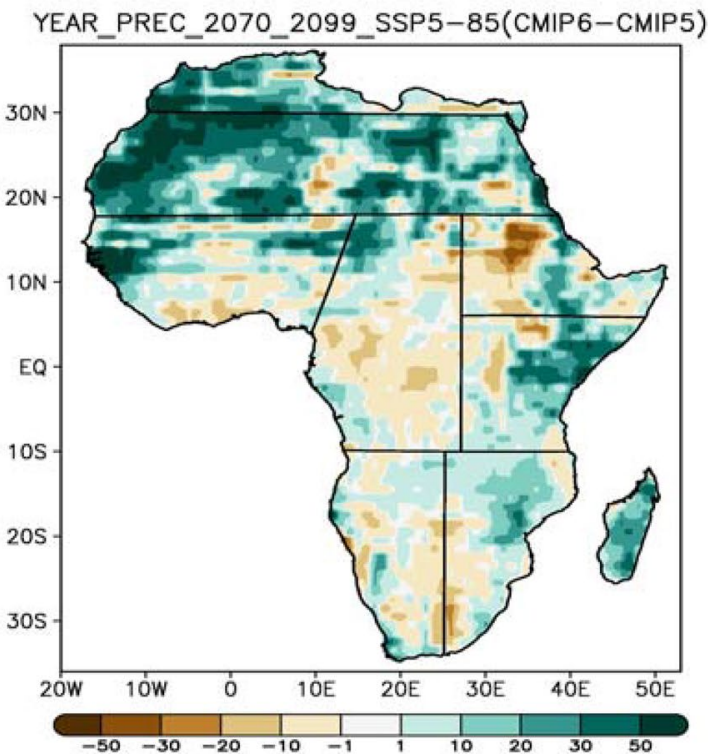

Fig. 14 Same as Fig. 13 except showing difference in annual precipitation in \%

Africa, namely NAF, SAH, WAF, CAF, CEAF, NEAF, SWAF, and SEAF, is projected to increase by $2.2(5.0){ }^{\circ} \mathrm{C}$, $2.2(5.3){ }^{\circ} \mathrm{C}, 1.7(4.2){ }^{\circ} \mathrm{C}, 1.6(3.7){ }^{\circ} \mathrm{C}, 1.5(3.5){ }^{\circ} \mathrm{C}, 1.7$ (4.1) ${ }^{\circ} \mathrm{C}, 1.9(4.7){ }^{\circ} \mathrm{C}$, and $1.7(4.0){ }^{\circ} \mathrm{C}$, respectively, under the SSP5-8.5 scenario. The projected temperature during boreal winter and summer also shows greater warming over northern Africa as compared with other regions.

On the other hand, projected precipitation over Africa shows substantial spatial variability and seasonal dependency during the twenty-first century. The northern and southern parts of Africa show a robust reduction in annual precipitation while the central parts of Africa show an increase under the three SSP scenarios in both the nearand long-term periods. The area-averaged precipitation at the continental scale revealed an increasing trend in annual precipitation over Africa under all scenarios. For the near (long)-term period, the area-averaged precipitation over Africa is projected to increase by $6.2(4.8) \%, 6.8(8.5) \%$, and 9.5 (15.2)\% under SSP1-2.6, SSP2-4.5, and SSP5-8.5, respectively. The uncertainty associated with precipitation is also large relative to that in projected temperature. This uncertainty associated with projected precipitation under SSP1-2.6, SSP2-4.5, and SSP5-8.5 is -5.2 to $20.7 \%$ ( -9.1 to $20.0 \%),-10.3$ to $27.6 \%$ ( -9.7 to $45.0 \%$ ), and -4.9 to $47.1 \%$ ( -7.8 to $200.3 \%$ ), respectively, for the near (long)term period. The projected seasonal precipitation pattern shows a robust reduction in boreal winter over northern parts of Africa, while the boreal summer pattern shows the opposite of boreal winter, with even reduced precipitation over southern parts of Africa. Central Africa shows an increase in 
projected precipitation, with a slight north-south shift in the maximum precipitation band during both seasons.

The comparison between the CMIP5 and CMIP6 model ensembles shows enhanced warming projected by CMIP6 more or less over the entire continent, with much higher warming over Northern Africa. Precipitation shows a mixed pattern, with the CMIP6 model ensemble simulating less precipitation over SWAF, CAF, and NEAF than the CMIP5 ensemble, while projecting a higher amount of precipitation over NAF, SAH, CEAF, and western WAF as compared with CMIP5.

This study is among the initial assessments of a CMIP6 climate model ensemble over the African continent in which a large number of climate models have been employed. It offers useful information about the regional patterns of projected temperature and precipitation and can serve as a reference, providing first-hand information based on the new generation of climate models over the continent.

Acknowledgments The authors thank the three anonymous reviewers for their insightful comments. This research work is supported financially by the Center of Excellence for Climate Change Research, King Abdulaziz University, Jeddah, Saudi Arabia. The authors thank the World Climate Research Program for making the CMIP6 dataset available for global and regional scale climate research. The authors also thank the Earth System Grid Federation (ESGF) for archiving and providing free access to the CMIP6 dataset. The computational work and data analysis were performed on the Aziz Supercomputer at King Abdulaziz University's High-Performance Computing Center, Jeddah, Saudi Arabia.

\section{Compliance with Ethical Standards}

Conflict of interest The authors declare that there is no conflict of interest with regard to this work and publication in this journal.

Open Access This article is licensed under a Creative Commons Attribution 4.0 International License, which permits use, sharing, adaptation, distribution and reproduction in any medium or format, as long as you give appropriate credit to the original author(s) and the source, provide a link to the Creative Commons licence, and indicate if changes were made. The images or other third party material in this article are included in the article's Creative Commons licence, unless indicated otherwise in a credit line to the material. If material is not included in the article's Creative Commons licence and your intended use is not permitted by statutory regulation or exceeds the permitted use, you will need to obtain permission directly from the copyright holder. To view a copy of this licence, visit http://creativecommons.org/licenses/by/4.0/.

\section{References}

Almazroui M, Saeed S et al (2017a) Assessment of uncertainties in projected temperature and precipitation over the Arabian Peninsula: a comparison between different categories of CMIP3 models. Earth Syst Environ. https://doi.org/10.1007/s41748-017-0012-z

Almazroui M, Nazrul Islam M et al (2017b) Assessment of uncertainties in projected temperature and precipitation over the Arabian Peninsula using three categories of Cmip5 multimodel ensembles.
Earth Syst Environ 1(2):1-20. https://doi.org/10.1007/s4174 8-017-0027-5

Anyah RO, Qiu W (2012) Characteristic 20th and 21st century precipitation and temperature patterns and changes over the Greater Horn of Africa. Int J Climatol. https://doi.org/10.1002/joc.2270

Barkhordarian A, Bhend J, von Storch H (2012) Consistency of observed near surface temperature trends with climate change projections over the Mediterranean region. Clim Dyn 38(910):1695-1702. https://doi.org/10.1007/s00382-011-1060-y

Barkhordarian A, von Storch H, Bhend J (2013) The expectation of future precipitation change over the Mediterranean region is different from what we observe. Clim Dyn. https://doi. org/10.1007/s00382-012-1497-7

Barros VR et al (2014) Climate change 2014 impacts, adaptation, and vulnerability Part B: regional aspects: working group II contribution to the fifth assessment report of the intergovernmental panel on climate change. https://doi.org/10.1017/CBO97 81107415386

Becker A et al (2013) A description of the global land-surface precipitation data products of the Global Precipitation Climatology Centre with sample applications including centennial (trend) analysis from 1901-present. Earth Syst Sci Data. https://doi.org/10.5194/ essd-5-71-2013

Bi D, Dix M, Marsland S et al (2012) The ACCESS coupled model: description, control climate and evaluation. Aust Meteorol Oceanogr J 63:41-64. https://doi.org/10.22499/2.6301.004

Bucchignani E et al (2018) Climate change projections for the Middle East-North Africa domain with COSMO-CLM at different spatial resolutions. Adv Clim Change Res. https://doi.org/10.1016/j.accre .2018 .01 .004

Cao J, Wang B, Yang Y-M, Ma L, Li J, Sun B, Bao Y, He J, Zhou X, Wu L (2018) The NUIST Earth System Model (NESM) version 3: description and preliminary evaluation. Geosci Model Dev 11:2975-2993. https://doi.org/10.5194/gmd-11-2975-2018

Christy JR, Norris WB, McNider RT (2009) Surface temperature variations in east Africa and possible causes. J Clim. https://doi. org/10.1175/2008JCLI2726.1

Collins JM (2011) Temperature variability over Africa. J Clim. https:// doi.org/10.1175/2011JCLI3753.1

Diedhiou A et al (2018) Changes in climate extremes over West and Central Africa at $1.5^{\circ} \mathrm{C}$ and $2^{\circ} \mathrm{C}$ global warming. Submitted. https ://doi.org/10.1088/1748-9326/aac3e5

Diffenbaugh NS, Giorgi F (2012) Climate change hotspots in the CMIP5 global climate model ensemble. Clim Change. https:// doi.org/10.1007/s 10584-012-0570-x

Djili B, Hamdi-Aïssa B (2018) Characteristics and mineralogy of desert alluvial soils: Wadi Zegrir, Northern Sahara of Algeria. Arid Land Res Manag. https://doi.org/10.1080/15324982.2017.1384413

Eyring V et al (2016) Overview of the coupled model intercomparison project phase 6 (CMIP6) experimental design and organization. Geosci Model Dev. https://doi.org/10.5194/gmd-9-1937-2016

Gidden MJ et al (2019) Global emissions pathways under different socioeconomic scenarios for use in CMIP6: a dataset of harmonized emissions trajectories through the end of the century. Geosci Model Dev. https://doi.org/10.5194/gmd-12-1443-2019

Giorgi F, Lionello P (2008) Climate change projections for the Mediterranean region. Glob Planet Change. https://doi.org/10.1016/j. gloplacha.2007.09.005

Gutjahr O, Putrasahan D, Lohmann K, Jungclaus JH, von Storch J-S, Brüggemann N, Haak H, Stössel A (2019) Max Planck Institute Earth System Model (MPI-ESM1.2) for the High-Resolution Model Intercomparison Project (HighResMIP). Geosci Model Dev 12:3241-3281. https://doi.org/10.5194/gmd-12-3241-2019

Haensler A, Saeed F, Jacob D (2013) Assessing the robustness of projected precipitation changes over central Africa on the basis of a 
multitude of global and regional climate projections. Clim Change 121:349-363. https://doi.org/10.1007/s10584-013-0863-8

Hajima T, Watanabe M, Yamamoto A, Tatebe H, Noguchi MA, Abe M, Ohgaito R, Ito A, Yamazaki D, Okajima H, Ito A, Takata K, Ogochi K, Watanabe S, Kawamiya M (2019) Description of the MIROC-ES2L Earth system model and evaluation of its climate-biogeochemical processes and feedbacks. Geosci Model Dev Discuss. https://doi.org/10.5194/gmd-2019-275 (in review)

Harris I et al (2014) Updated high-resolution grids of monthly climatic observations - the CRU TS310 dataset. Int J Climatol. https://doi. org/10.1002/joc.3711

He B et al (2019) CAS FGOALS-f3-L model datasets for CMIP6 historical Atmospheric Model Inter-comparison Project simulation. Adv Atmos Sci 36(8):771-778. https://doi.org/10.1007/s0037 6-019-9027-8

Held IM, Guo H, Adcroft A, Dunne JP, Horowitz LW, Krasting J et al (2019) Structure and performance of GFDL's CM4.0 climate model. J Adv Model Earth Syst. https://doi.org/10.1029/2019M S001829

Hoerling M et al (2006) Detection and attribution of twentieth-century northern and southern African rainfall change. J Clim. https://doi. org/10.1175/JCLI3842.1

IPCC (2013) Working Group I contribution to the IPCC fifth assessment report, climate change 2013: The Physical Science Basis, IPCC

Iturbide M, Gutiérrez JM, Alves LM et al (2020) An update of IPCC climate reference regions for subcontinental analysis of climate model data: definition and aggregated datasets. Earth Syst Sci Data. https://doi.org/10.5194/essd-2019-258

Jones PW (1999) First- and second-order conservative remapping schemes for grids in spherical coordinates. Mon Weather Rev. https://doi.org/10.1175/1520-0493(1999)127\%3c2204:FASOC $\mathrm{R} \% 3 \mathrm{e} 2.0 . \mathrm{CO} ; 2$

Jones PD, Moberg A (2003) Hemispheric and large-scale surface air temperature variations: an extensive revision and an update to 2001. J Clim. https://doi.org/10.1175/15200442(2003)016\%3c0206:HALSSA\%3e2.0.CO;2

Kalognomou EA et al (2013) A diagnostic evaluation of precipitation in CORDEX models over Southern Africa. J Clim. https://doi. org/10.1175/JCLI-D-12-00703.1

Klutse NAB et al (2018) Potential impact of $1.5^{\circ} \mathrm{C}$ and $2{ }^{\circ} \mathrm{C}$ global warming on consecutive dry and wet days over West Africa. Environ Res Lett 13(5):055013. https://doi.org/10.1088/1748-9326/ aab37b

Kruger AC, Sekele SS (2013) Trends in extreme temperature indices in South Africa: 1962-2009. Int J Climatol. https://doi.org/10.1002/ joc. 3455

Kruger AC, Shongwe S (2004) Temperature trends in South Africa: 1960-2003. Int J Climatol. https://doi.org/10.1002/joc.1096

Lauritzen PH, Nair RD, Herrington AR, Callaghan P, Goldhaber S, Dennis JM et al (2018) NCAR release of CAM-SE in CESM2.0: A reformulation of the spectral element dynamical core in drymass vertical coordinates with comprehensive treatment of condensates and energy. J Adv Model Earth Syst 10:1537-1570. https ://doi.org/10.1029/2017MS001257

Law RM, Ziehn T, Matear RJ, Lenton A, Chamberlain MA, Stevens LE, Wang Y-P, Srbinovsky J, Bi D, Yan H, Vohralik PF (2017) The carbon cycle in the Australian Community Climate and Earth System Simulator (ACCESS-ESM1) - Part 1: model description and pre-industrial simulation. Geosci Model Dev 10:2567-2590. https://doi.org/10.5194/gmd-10-2567-2017

Lebel T, Ali A (2009) Recent trends in the Central and Western Sahel rainfall regime (1990-2007). J Hydrol. https://doi.org/10.1016/j. jhydrol.2008.11.030
Lelieveld J et al (2012) Climate change and impacts in the Eastern Mediterranean and the Middle East. Clim Change. https://doi. org/10.1007/s 10584-012-0418-4

Lelieveld J et al (2016) Strongly increasing heat extremes in the Middle East and North Africa (MENA) in the 21st century. Clim Change 137(1-2):245-260. https://doi.org/10.1007/s10584-016-1665-6

Li L (2019) CAS FGOALS-g3 model output prepared for CMIP6 ScenarioMIP ssp370 (Version 20191026) [Data set]. Earth System Grid Fed. https://doi.org/10.22033/ESGF/CMIP6.3480

Libanda B, Ngonga C (2018) Projection of frequency and intensity of extreme precipitation in Zambia: a CMIP5 study. Clim Res 76(1):59-72

Liebmann B et al (2012) Seasonality of African precipitation from 1996 to 2009. J Clim. https://doi.org/10.1175/JCLI-D-11-00157.1

Lyon B, Dewitt DG (2012) A recent and abrupt decline in the East African long rains. Geophys Res Lett. https://doi.org/10.1029/2011G L050337

MacKellar N, New M, Jack C (2014) Observed and modelled trends in rainfall and temperature for South Africa: 1960-2010. S Afr J Sci. https://doi.org/10.1590/sajs.2014/20130353

Massonnet F, Ménégoz M, Acosta M, Yepes-Arbós X, Exarchou E, Doblas-Reyes FJ (2020) Replicability of the EC-Earth3 Earth system model under a change in computing environment. Geosci Model Dev 13:1165-1178. https://doi.org/10.5194/ gmd-13-1165-2020

Mauritsen T, Bader J, Becker T, Behrens J, Bittner M, Brokopf R et al (2019) Developments in the MPI-M Earth System Model version 1.2 (MPI-ESM1.2) and its response to increasing CO2. J Adv Model Earth Syst 11:998-1038. https://doi.org/10.1029/2018M S001400

Mohamed AB (2011) Climate change risks in Sahelian Africa. Reg Environ Change. https://doi.org/10.1007/s10113-010-0172-y

Munday C, Washington R (2018) Systematic climate model rainfall biases over Southern Africa: links to moisture circulation and topography. J Clim 31:7533-7548. https://doi.org/10.1175/ JCLI-D-18-0008.1

New $M$ et al (2006) Evidence of trends in daily climate extremes over southern and west Africa. J Geophys Res Atmos. https://doi. org/10.1029/2005JD006289

Niang I et al (2015) 'Africa', Climate change 2014: Impacts, adaptation and vulnerability: Part B: regional aspects: working group II contribution to the fifth assessment report of the intergovernmental panel on climate change. pp 1199-1266. https://doi.org/10.1017/ cbo9781107415386.002

Nicholson SE et al (2013) Temperature variability over Africa during the last 2000 years. Holocene. https://doi.org/10.1177/09596 83613483618

Nikulin G et al (2012) Precipitation climatology in an ensemble of CORDEX-Africa regional climate simulations. J Clim. https:// doi.org/10.1175/JCLI-D-11-00375.1

O'Neill BC et al (2016) The scenario model intercomparison project (ScenarioMIP) for CMIP6. Geosci Model Dev. https://doi. org/10.5194/gmd-9-3461-2016

Ongoma V, Chena H, Gaoa C (2018) Projected changes in mean rainfall and temperature over east Africa based on CMIP5 models. Int J Climatol. https://doi.org/10.1002/joc.5252

Orlowsky B, Seneviratne SI (2012) Global changes in extreme events: regional and seasonal dimension. Clim Change. https://doi. org/10.1007/s10584-011-0122-9

Rong XY, Li J, Chen HM, et al (2019) Introduction of CAMS-CSM model and its participation in CMIP6. Clim Chang Res. 15(5):540 544. https://doi.org/10.12006/j.issn.1673-1719.2019.186

Saeed S et al (2017) Multidecadal convection permitting climate simulations over Belgium: sensitivity of future precipitation extremes. Atmos Sci Lett 18(1):29-36. https://doi.org/10.1002/asl.720 
Séférian R, Nabat P, Michou M, Saint-Martin D, Voldoire A, Colin J et al (2019) Evaluation of CNRM Earth-System model, CNRMESM2-1: role of Earth system processes in present-day and future climate. J Adv Model Earth Syst. https://doi.org/10.1029/2019M S001791

Seland $\varnothing$, Bentsen M, Seland Graff L, Olivié D, Toniazzo T, Gjermundsen A, Debernard JB, Gupta AK, He Y, Kirkevåg A, Schwinger J, Tjiputra J, Schancke Aas K, Bethke I, Fan Y, Griesfeller J, Grini A, Guo C, Ilicak M, Hafsahl Karset IH, Landgren O, Liakka J, Onsum Moseid K, Nummelin A, Spensberger C, Tang H, Zhang Z, Heinze C, Iverson T, Schulz M (2020) The Norwegian Earth System Model, NorESM2 - Evaluation of theCMIP6 DECK and historical simulations. Model Dev Discuss Geosci. https://doi.org/10.5194/gmd-2019-378 (in review)

Sellar A, Jones C, Mulcahy J, Tang Y, Yool A, Wiltshire A, O'Connor F, Stringer M, Hill R, Palmieri J, Woodward S, Mora L, Kuhlbrodt T, Rumbold S, Kelley D, Ellis R, Johnson C, Walton J, Abraham N, Andrews M, Andrews T, Archibald A, Berthou S, Burke E, Blockley E, Carslaw K, Dalvi M, Edwards J, Folberth G, Gedney N, Griffiths P, Harper A, Hendry M, Hewitt A, Johnson B, Jones A, Jones C, Keeble J, Liddicoat S, Morgenstern O, Parker R, Predoi V, Robertson E, Siahaan A, Smith R, Swaminathan R, Woodhouse M, Zeng G, Zerroukat M (2019) UKESM1: Description and evaluation of the UK Earth System Model. J Adv Model Earth Syst. https://doi.org/10.1029/2019MS001739

Solomon S et al (2007) Contribution of working group I to the fourth assessment report of the intergovernmental panel on climate change

Song ZY, Bao Y, Qiao FL (2019) Introduction of FIO-ESM v2.0 and its participation plan in CMIP6 experiments. J Clim Change Res 15(5):558-565

Stern DI et al (2011) Temperature and malaria trends in highland East Africa. PLoS ONE. https://doi.org/10.1371/journal.pone.0024524

Sutton MA et al (2011) Summary for policy makers. Eur Nitrogen Assess. https://doi.org/10.1017/cbo9780511976988.002

Swart NC, Cole JNS, Kharin VV, Lazare M, Scinocca JF, Gillett NP, Anstey J, Arora V, Christian JR, Hanna S, Jiao Y, Lee WG, Majaess F, Saenko OA, Seiler C, Seinen C, Shao A, Sigmond M, Solheim L, von Salzen K, Yang D, Winter B (2019) The Canadian Earth System Model version 5 (CanESM5.0.3). Geosci Model Dev 12:4823-4873. https://doi.org/10.5194/gmd-12-4823-2019

Sylla MB et al (2013) Uncertainties in daily rainfall over Africa: assessment of gridded observation products and evaluation of a regional climate model simulation. Int J Climatol 33:1805-1817. https:// doi.org/10.1002/joc.3551
Sylla MB et al (2016) Climate change over West Africa: recent trends and future projections. Adap Clim Change Var Rural West Afr 1700:25-40. https://doi.org/10.1007/978-3-319-31499-0

Sylla MB et al (2018) Projected heat stress under $1.5^{\circ} \mathrm{C}$ and $2{ }^{\circ} \mathrm{C}$ global warming scenarios creates unprecedented discomfort for humans in West Africa. Earth's Future. https://doi.org/10.1029/2018e f000873

Tatebe H, Ogura T, Nitta T, Komuro Y, Ogochi K, Takemura T, Sudo K, Sekiguchi M, Abe M, Saito F, Chikira M, Watanabe S, Mori M, Hirota N, Kawatani Y, Mochizuki T, Yoshimura K, Takata K, O'ishi R, Yamazaki D, Suzuki T, Kurogi M, Kataoka T, Watanabe M, Kimoto M (2019) Description and basic evaluation of simulated mean state, internal variability, and climate sensitivity in MIROC6. Geosci Model Dev 12:2727-2765. https://doi. org/10.5194/gmd-12-2727-2019

Trenberth KE (2007) Observations: surface and atmospheric climate change. Changes. https://doi.org/10.5194/cp-6-379-2010

Vizy EK, Cook KH (2012) Mid-twenty-first-century changes in extreme events over northern and tropical Africa. J Clim. https:// doi.org/10.1175/JCLI-D-11-00693.1

Voldoire A, Saint-Martin D, Sénési S, Decharme B, Alias A, Chevallier M et al (2019) Evaluation of CMIP6 DECK experiments with CNRM-CM6-1. J Adv Model Earth Syst 11:2177-2213. https:// doi.org/10.1029/2019ms001683

Volodin EM, Mortikov EV, Kostrykin SV, Galin VY, Lykossov VN, Gritsun AS, Diansky NA, Gusev AV, Iakovlev NG, Shestakova AA, Emelina SV (2018) Simulation of the modern climate using the INM-CM48 climate model. Russ J Numer Anal Math Model 33(6):367-374. https://doi.org/10.1515/rnam-2018-0032

Wang B, Biasutti M, Byrne M et al (2020) Monsoon climate change assessment. Bull Am Meteor Soc. https://doi.org/10.1175/ BAMS-D-19-0335.1

Wu T, Lu Y, Fang Y, Xin X, Li L, Li W, Jie W, Zhang J, Liu Y, Zhang L, Zhang F, Zhang Y, Wu F, Li J, Chu M, Wang Z, Shi X, Liu X, Wei M, Huang A, Zhang Y, Liu X (2019) The Beijing climate center climate system model (BCC-CSM): the main progress from CMIP5 to CMIP6. Geosci Model Dev 12:1573-1600. https://doi. org/10.5194/gmd-12-1573-2019

Yukimoto S, Kawai H, Koshiro T, Oshima N, Yoshida K, Urakawa S, Tsujino H, Deushi M, Tanaka T, Hosaka M, Yabu S, Yoshimura H, Shindo E, Mizuta R, Obata A, Adachi Y, Ishii M (2019) The meteorological research institute earth system model version 2.0, MRI-ESM2.0: description and basic evaluation of the physical component. J Meteor Soc Jpn. https://doi.org/10.2151/ jmsj.2019-051 